This is the final peer-reviewed accepted manuscript of

Franzellitti S.; Canesi L.; Auguste M.; Wathsala R. H. G. R.; Fabbri E.: Microplastic exposure and effects in aquatic organisms: A physiological perspective. ENVIRONMENTAL TOXICOLOGY AND PHARMACOLOGY 68. ISSN 1382-6689.

DOI: 10.1016/j.etap.2019.03.009

The final published version is available online at:

http://dx.doi.org/10.1016/j.etap.2019.03.009

Rights / License: The terms and conditions for the reuse of this version of the manuscript are specified in the publishing policy. For all terms of use and more information see the publisher's website. 


\title{
Microplastic exposure and effects in aquatic organisms: A physiological perspective
}

\author{
Silvia Franzellitti ${ }^{\mathrm{a}, *}$, Laura Canesi $^{\mathrm{b}}$, Manon Auguste ${ }^{\mathrm{b}}$, Rajapaksha H.G.R. Wathsala ${ }^{\mathrm{a}}$, Elena Fabbri ${ }^{\mathrm{a}}$ \\ ${ }^{\mathrm{a}}$ Animal and Environmental Physiology Laboratory, Department of Biological, Geological and Environmental Sciences (BIGEA), University of Bologna, Ravenna, Italy ${ }^{\mathrm{b}}$ \\ Department of Earth, Environment and Life Sciences (DISTAV), University of Genoa, Genova, Italy
}

\section{A R T I C L E I N F O}

Keywords:

Microplastic

Aquatic animals

Tissue distribution

Ingestion

Physiological effects

Plastic leachates

\begin{abstract}
A B S T R A C T
The impact of microplastics (MPs) on aquatic life, given their ubiquitous presence in the water compartment, represents a growing concern. Consistently, scientific knowledge is advancing rapidly, although evidence on actual adverse effects is still highly fragmented. This paper summarizes the recent literature on MP impacts on aquatic organisms in an attempt to link routes of uptake, possible alterations of physiological processes, and outcomes at different levels of biological organization. Animal feeding strategies and MP biodistribution is discussed, alongside with relevant effects at molecular, cellular, and systemic level. Pathways from animal exposure to apical physiological responses are examined to define the relevance of MPs for animal health, and to point out open questions and research gaps. Emphasis is given to emerging threats posed by leaching of plastic additives, many of which have endocrine disruption potential. The potential role of MPs as substrates for microorganism growth and vehicle for pathogen spreading is also addressed.
\end{abstract}

\section{Introduction}

Pollution of aquatic environments by microplastics (MPs), defined as plastic particles of size $\leq 5 \mathrm{~mm}$ (UNEP, 2016), originates from the release of primary manufactured particles employed in many industrial and household activities, as well as from the degradation of larger plastics items into micro sized fragments (Andrady, 2017). The amount of MPs released in the environment is likely to increase as a result of the ongoing growth in the production of plastics worldwide (Plastics Europe, 2018), while degradation is expected over hundreds of years.

The effects of MPs on aquatic organisms are currently the subject of intense research, with an exponential rise in the last few years in publications reporting data from different taxonomic groups, from laboratory and field investigations, as well as on the role of MPs as vectors for organic contaminants. A Pubmed research on 'Microplastics \& Effects \& Aquatic' gave 129 hits, with an increase from 6 in 2014 2015 to 58 in 2018; these include at least 20 reviews intended to give a critical perspective on the ecotoxicological consequences of MP ingestion in aquatic biota. In particular, Burns and Boxall (2018) and de Sá et al. (2018) focused on the major knowledge gaps concerning the effects of MPs on aquatic organisms, underlying the mismatch between particle types, size ranges, and concentrations of MPs used in laboratory tests compared to those measured in the environment. Moreover, these Authors addressed the need to understand the mechanisms of action and the capacity of MPs to exert cellular and systemic effects at environmentally relevant concentrations.

This paper will review the most recent literature on the biological impacts of MPs on aquatic organisms Animal feeding strategies and their impacts on the routes of MP uptake and accumulation in different tissues are considered. Moreover, the most relevant effects observed at the molecular, cellular, and systemic level in aquatic species exposed to MPs are discussed.

Where needed, findings related to particles of smaller size (up to 1 $\mu \mathrm{m}$; Gigault et al. (2018)) classified as nanoplastics (NPs) are also reported as they can provide relevant hints into the biological impacts of small size MPs, particularly in relation to translocation pathways and accumulation at the tissue level.

Overall, building on knowledge gained by previous reviews and meta analyses (Foley et al., 2018; Galloway and Lewis, 2016; Paul Pont et al., 2018), this paper attempts to deeply examine relationships be tween animal exposure, alterations of physiological mechanisms and apical responses, in order to better define the relevance of MP exposure for the health status of aquatic organisms, and to point out currently open questions and research gaps. Finally, emphasis is posed towards

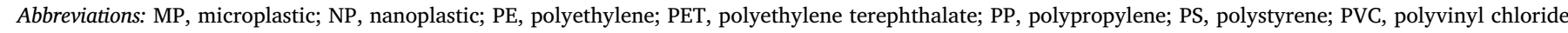
* Corresponding author at: Department of Biological, Geological and Environmental Sciences (BIGEA), University of Bologna, Via Sant'Alberto 163, 48123,

Ravenna, Italy.

E-mail address: silvia.franzellitti@unibo.it (S. Franzellitti). 
emerging biological threats of MP occurrence in aquatic environments, such as leaching of plastic additives, which have the potential to exert adverse effects on aquatic fauna, and the role of MPs as substrate of microorganism growth, which is likely to promote the spread of pathogens as well as the invasion by alien species.

\section{Routes of uptake and distribution of microplastics in aquatic organisms}

2.1. Uptake mechanisms: indiscriminate feeding vs active selection, and trophic transfer

Given their size range, MPs may fall within the optimal prey range for a variety of aquatic animals. such as zooplankton, mollusks, crustacea, fish, seabirds, and marine mammals, and thus be bioavailable for ingestion (Browne et al., 2008; Cole et al., 2013; Germanov et al., 2018; Lusher et al., 2017). Routes of direct ingestion include particle uptake by filter, suspension and deposit feeders, that have a relatively in discriminate feeding behaviors by collecting and sorting particulate matter to trap and ingest anything of appropriate size (Moore, 2008). Uptake efficiency also depends on the combination of particle size, shape, and density that determine MP position in the water column and/ or sediments, and hence their availability to animals. Typically, low density polymers like PP and PE float in the water column, while high density MPs like PS and PVC sink and accumulate into sediments, making them more available to filter/suspension or deposit feeders, respectively (Browne et al., 2017; Chubarenko et al., 2016). This issue was addressed in a mesocosm study reproducing PS MP exposure (10 $\mu \mathrm{m} ; 5,50$ and 250 particle $/ \mathrm{mL}$ ) on a coastal community consisting of dominant invertebrate taxa of the Northern Baltic Sea clearly (Setälä et al., 2016). The results showed that the lowest number of ingested particles was detected in the polychaetes Marenzelleria spp. and Monoporeia affinis, both deposit feeders living either in burrows (Mar enzelleria spp) or at the sediment surface ( $M$. affinis). The bivalves Mytilus trossulus and Macoma balthica, filter feeders at the sediment water interface, contained comparatively higher amounts of particles. Uptake of MPs (1, 10 and $90 \mu \mathrm{m}$ PS spheres at 33000 particle/mL) was investigated in freshwater invertebrates with different feeding strate gies (Scherer et al., 2017). All species ingested MPs in a concentration dependent manner with the copepod Daphnia magna, a pelagic filter feeder, consuming up to 6180 particle/h, and exhibiting higher feeding rates on 1 and $10 \mu \mathrm{m}$ beads compared to the aquatic larvae of the diptera Chironomus riparius and the freshwater worm Lumbriculus var iegatus, a burrowing and detritivorous species.

The above studies suggest that filter feeders are the most prone to ingestion of suspended MPs. These organisms form important links between different trophic levels and between pelagic and benthic ecosystems, hence representing a possible route of trophic transfer for MPs. Recently, the concept that a filter feeding habit may pose a greater risk for MP ingestion was discussed for marine megafauna, in particular to mobulid rays, sharks, and baleen whales (Germanov et al., 2018). These animals have even a higher probability of ingesting relevant amounts of MPs, because they must filter hundreds to thousands of liters of water per day to gain adequate nutrition (Paig Tran et al., 2013). Therefore, they are likely to ingest MPs both directly from water and indirectly, through contaminated planktonic prey (Dawson et al., 2018; Setälä et al., 2014). Indeed, the estimated daily MP ingestion rates range from a minimum of about 100 pieces for whale sharks from the Gulf of $\mathrm{Ca}$ lifornia (Fossi et al., 2017), to thousands of pieces for fin whales in habiting the Mediterranean Sea (Fossi et al., 2012). This might lead to a significant reduction in their nutritional uptake, as animals feed on the same quantities of particulate matter but receive a lower nutritional benefit (Germanov et al., 2018).

In addition to feeding habits, the mechanism of ingestion and the structure of digestive organs also affect the uptake of MPs. For example, field surveys showed that sea cucumbers (Apostichopus japonicus) select the size of the ingested MPs as long as MPs can fit into their mouth or the tentacles are able to grasp them (Mohsen et al., 2019). Jabeen et al. (2017) showed that in freshwater fish plastic items are likely to accumulate in intestines with more complex coiled structures. Stomachs with a narrow opening to the intestines seemed to retain more plastics. In this light, the results indicate that the presence of complex stomachs and intestines may increase the chances of plastic accumulation and potential damage. The Authors further highlighted that morphological differences in the gastrointestinal tract are related to feeding habits; therefore, the whole structure of the gut and the digestion process should be considered in future investigations on plastic ingestion and effects in fish.

Active selection due to misidentification of MPs for food was also demonstrated. The general idea is that since plastics are not composed of known phagostimulants, their consumption should result from visual or tactile misidentification (Moore, 2008). Visual similarity between plastic debris and preys is suggested to drive plastic ingestion by big aquatic vertebrates such as sea turtles (Schuyler et al. (2014) and re ference therein). A similar phenomenon was also observed in small fish or crustacea. For example, omnivorous juveniles of the tropical fish Girella laevifrons, collected from tidal pools from Las Cruces (Chile), preferentially ingested red colored plastic fibers, since their diet is mainly based on grazing red algae dominating bottom habitats at the sampling locations (Mizraji et al., 2017). Similarly, the planktivorous fish Seriolella violacea preferentially captured black MPs, likely because they appear more similar to food pellets, whereas MPs of other colors (blue, translucent, and yellow) were co captured only when floating close to food pellets (Ory et al., 2018). In contrast, an example of MP avoidance likely due to visual recognition is provided by a laboratory study in which zebrafish exposed to MPs were able to recognize them as "non food" and react negatively exhibiting a spitting locomotory be havior (Kim et al., 2019). Zebrafish is equipped with a diurnal adapted visual system, and it can adjust its movements according to the azimuth of preys (Patterson et al., 2013). In addition, zebrafish displayed good learning and memory abilities, exhibiting long term behavioral adaptations for judging whether MP was food or not (Kim et al., 2019).

Mysid shrimps (Praunus spp.) are known to actively select their preys (Viherluoto and Viitasalo, 2001a), thus they may discriminate MP fragments from their mesozooplankton preys. Size selective feeding over MPs of different size classes and irregular shape was observed, since only fragments of a certain size fraction $(100200 \mu \mathrm{m})$ were se lected over other MP sizes ( $<90 \mu \mathrm{m}$ and $>500 \mu \mathrm{m}$ ) (Lehtiniemi et al., 2018). Particle colors (orange, green, red, and yellow) did not affect selection, in agreement with the finding that mysids locate their prey mainly by mechanoreception (Viherluoto and Viitasalo, 2001b).

Evidence of ingestion due to chemical cues is reported in a wide range of aquatic animals, from cnidarians (Allen et al., 2017), to bivalve mollusks (Bråte et al., 2018) and fish (Savoca et al., 2017). Surface coverage by mixtures of organic and inorganic moleculesis the first modification of surface properties that occurs when MPs are introduced into natural waters, as this brings them into contact with natural colloids, inorganic (ionic compounds and minerals) and organic matter (i.e., mixtures of polysaccharides, proteins, lipids, and nucleic acids), forming a so called "eco bio corona" (Canesi et al., 2016; Canesi and Corsi, 2016). Moreover, MPs can be colonized by microorganisms (Galloway et al., 2017), leading to a formation of a biofilm that can contain microbes similar to those feeding in the water column (Vroom et al., 2017), or bacteria produced exudates acting as infochemicals of food occurrence. For example, DMS (dimethyl sulfide) and its precursor DMSP (dimethylsulfonio propionate) have been identified to drive plastic selection by seabirds and fish (Savoca et al., 2017, 2016). DMS is produced by the enzymatic breakdown of DMSP, which increases during zooplankton grazing (Dacey and Wakeham, 1986), hence it triggers foraging activity for those species whose diet is rich in pelagic crustaceans (DeBose et al., 2008). As a result, preferential ingestion of weathered over virgin MPs was observed in different aquatic organisms 
(Bråte et al., 2018; Reisser et al., 2014; Vroom et al., 2017). A first evidence of plastic litter ingestion by Pelagia noctiluca, the most abundant jellyfish species in the Mediterranean Sea, was reported by Macali et al. (2018). As with the distribution of plastic litter, the dispersal of this species is mainly driven by local winds and currents that con centrate this organism in regions with a high concentration of floating litter. The presence of PE plastic items in the gastrovascular cavity of the jellyfish was related to active ingestion of the fragments wrongly recognized as food, likely due to chemical cues derived by plastic weathering. It is worth noting that chemoreception is the main sensing mechanism controlling preying and feeding behavior in this species (Morabito et al., 2012). Laboratory experiments with the cnidarian coral Astrangia poculata showed nematocyst discharge and ingestion of different MPs (including PE) (Allen et al., 2017), supporting the hy pothesis that phagostimulants potentially found as components of the polymer matrix may promote chemoreception in cnidarians.

Beside the above listed factors that influence mechanical uptake, visual and chemical recognition, some other factors such as shape and hardness also affect the ingestion of MPs. For example, mysid shrimps (Praunus spp.) exposed to primary and secondary MPs within the size range of their prey mostly ingested smaller particles (100 $200 \mu \mathrm{m}$ ac rylonitrile butadiene styrene) and spherical primary PS MPs $(90 \mu \mathrm{m})$, while largest filamentous fragments originated from a soft drink bottle (200 $1500 \mu \mathrm{m}$ polyethylene terephthalate) provoked animal entangle ment (Lehtiniemi et al., 2018).

Microplastics may be also ingested indirectly through trophic transfer, whereby contaminated preys are consumed by predators (Au et al., 2017). This issue is the subject of increased scientific debate, in light of the implications of a high seafood diet and related human health effects (Carbery et al., 2018). Laboratory studies gained con vincing evidence that trophic transfer does occur for low trophic level organisms. For example, in feeding experiments under controlled, conditions blue mussels (Mytilus edulis) were exposed to fluorescently labelled $0.5 \mu \mathrm{m}$ PS MPs (at a concentration of about 1,000,000 particle/mL) before being fed to the common shore crab (Carcinus maenas)(Farrell and Nelson, 2013). The analysis of crab tissues revealed the presence of MPs in the haemolymph, stomach, hepatopancreas, ovary and gills. It must be noted that selected exposure levels of MPs far ex ceeded those from natural field conditions. A less extreme exposure scenario was employed by Santana et al. (2017). Exposure conditions (MP concentrations, exposure duration, time of post exposure depura tion) were settled to allow MPs $(0.11 .0 \mu \mathrm{m}$ PVC spherical particles) being detected only in the hemolymph and being absent in the gut cavity of the prey (the mussel Perna perna). Predators were the crab Callinectes ornatus and the pufferfish Spheoeroides greeleyi. PVC MPs were shown to be transferred from prey to predators but with no evi dence of tissue accumulation after 10 days of exposure. The Authors hypothesized a reduced likelihood of trophic transfer of particles and, as a consequence, a reduced risk of direct impacts of MPs on higher trophic levels. Trophic transfer of PS NPs was shown in a freshwater food chain with the algae Chlamydomonas reinhardtii, the copepod D. magna, the secondary consumer Chinese medaka fish (Oryzias sinensis), and the end consumer Dark chub fish (Zacco temminckii) (Chae et al., 2018). Algae were exposed to $50 \mathrm{mg} / \mathrm{L}$ NPs, while higher trophic level organisms were exposed through their diet. Microscopy analyses confirmed that NPs adhered to the surface of the primary producer and were present in the digestive organs of the higher trophic level species. Under these exposure conditions, NPs negatively affected swimming activity of both fish species.

When investigating the fate and biological interactions of MPs in natural settings, it was shown that other factors beside the trophic level can influence the occurrence of MPs in wildlife (Bour et al., 2018a). Nevertheless, many evidences in support of trophic transfer occurring in natural aquatic food webs is accumulating. A first example was reported by Eriksson and Burton (2003) that, through field observations, showed the presence of MPs in the scats of Antarctic fur seals (Arcto cephalus tropicalis and A. gazelle) from Macquarie Island (Antarctica). The Authors suggested that MPs had initially been ingested by the plankton feeding fish, Electrona subaspera, which is the main prey consumed by fur seals in the area. Recently, investigations on stomach contents of wild caught plaices (Pleuronectes platessa) from the Celtic Sea demonstrated an active route of MP trophic transfer from plankton feeders sand eels (Ammodytes tobianus) (Welden et al., 2018). By analyzing MP content in scats from captive grey seals Halichoerus grypus (residents of a rehabilitation center) and the wild caught fish they are fed upon (the Atlantic mackerel Scomber scombrus), the study from Nelms et al. (2018) was the first to report empirical evidence for the trophic transfer of MPs to a marine top predator. Further evidence reporting MP occurrence within the gastro intestinal tracts of various wild caught fish species (Güven et al., 2017; Lusher et al., 2017) highlight the potential for MP ingestion through feeding on con taminated preys.

The reported findings suggest that trophic transfer represents a potentially relevant route of MP accumulation for any species whose feeding habit involves the consumption of whole prey (i.e. including gastrointestinal tracts), posing direct concerns to human health (EFSA, 2016). Further information on the mechanisms through which MPs transfer through the trophic chain potentially enter the human food chain are advisable.

\subsection{Tissue distribution of microplastics in aquatic organisms}

Generally speaking, MPs are thought to accumulate in aquatic or ganisms only in tissues in direct contact with water, such as gastrointestinal and respiratory tissues (Grigorakis et al., 2017; Jovanović, 2017; Nicolau et al., 2016). However, as long as scientific evidence is accumulating, it is becoming clear that other tissues may be impacted by particle accumulation (Fig. 1), arguing the onset of translocation processes, and broadening the potential impacts of MPs on a variety of physiological functions.

In bivalve mollusks, gills are a first site of particles uptake, mediated by microvilli activity and endocytosis, while a second route occurred via ciliary movement in the stomach, intestine and digestive tubules, followed by MP translocation towards haemolymph (Browne et al., 2008; Magni et al., 2018; Paul Pont et al., 2016; Sussarellu et al., 2016; Von Moos et al., 2012). The resulting accumulation pathway shows consistent aggregates within intestinal lumen and digestive tissues, and more limited MP occurrence in gill epithelial cells and in haemolymph

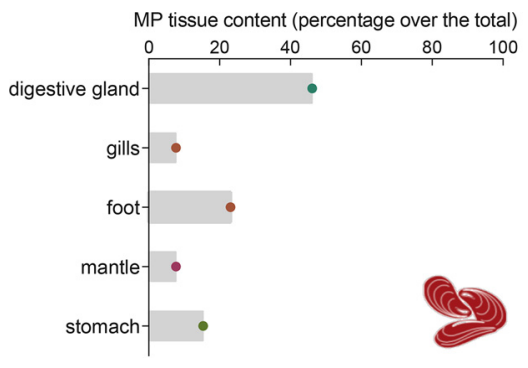

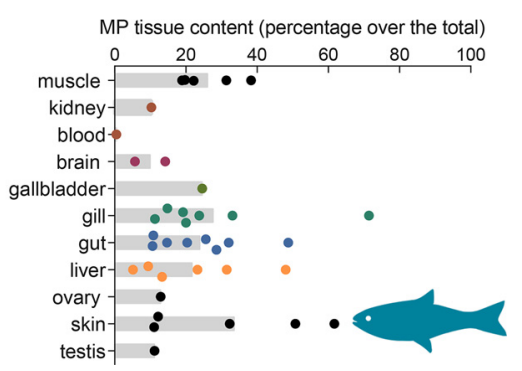

Fig. 1. Resume of the available data on tissue distribution of microplastics in bivalves (left panel) and fish (right panel). Dots represent point data retrieved from the literature and expressed as percentage of the total MP burden reported. Shaded bars are the mean values. Only papers assessing MP concentrations in multiple tissues were considered: Abbasi et al. (2018); Ding et al. (2018); Kashiwada (2006); Kolandhasamy et al. (2018); Lu et al. (2016). 
(Avio et al., 2015a; Von Moos et al., 2012). Browne et al. (2008) first showed that in M. edulis particle size influenced the capacity of MPs to translocate from the gut cavity to the hemolymph, with a higher percentage $(60 \%)$ of smaller particles $(3 \mu \mathrm{m})$ in the circulatory fluid than larger ones $(9.6 \mu \mathrm{m})$. However, confocal microscopy demonstrated that both MP sizes were present inside hemocytes. The formation of granulocytomas around accumulated PE MPs up to $80 \mu \mathrm{m}$ was also observed in the digestive gland of exposed mussels (Von Moos et al., 2012). These findings pointed out the key role of phagocytosis operated by hemo cytes in translocation events. Uptake of MPs in multiple organs of mussels under field conditions was recently reported by Kolandhasamy et al. (2018). The abundance of MPs by tissue weight showed significant differences amongst organs, with intestine containing the highest MP levels ( 9.2 items/g of tissue), surprisingly followed by foot, and then by stomach, gills, mantle, adductor muscle, gonads, and visceral mass. Adherence to soft tissues rather than ingestion was sug gested as a possible route of MP accumulation in those organs, such as foot, that are not involved in ingestion processes.

Watts et al. (2014) tested the hypothesis that the non filter feeding shore crab (Carcinus maenas) can take up MPs $(810 \mu \mathrm{m})$ both through inspiration across the gills and ingestion of pre exposed food (blue mussels, M. edulis). Gill mediated inspiration resulted in a 21 days MP body retention, while a 14 days body retention was observed following MP uptake through dietary ingestion. Most MPs were found on the external surface of gills following waterborne exposure or were retained in the foregut, due to adherence to the hair like setae, after dietary exposure. Jeong et al. (2017) showed that the fluorescence signal of labeled $50 \mathrm{~nm}$ PS NPs was dispersed throughout the body in exposed the marine copepod Paracyclopina nana, while florescence of $0.5 \mu \mathrm{m}$ and 6 $\mu \mathrm{m}$ size PS MPs was mostly restricted to digestive organs. The dispersed fluorescence observed in $50 \mathrm{~nm}$ NP exposed Physiological impacts of microplastic $P$. nana could be explained by translocation of PS particles across cellular membranes through the digestive organs.

In fish, the gastrointestinal tract is the most investigated organ in relation to accumulation of plastic litter, providing a means to derive information on presence, spatial distribution, and typology of litter in defined areas, or to assess MP body burden in species of commercial interest (Avio et al., 2015b; Pellini et al., 2018; Wieczorek et al., 2018). For example, digestive tracts of 263 individuals from 26 species of commercial fish caught off the Atlantic coasts of Portugal were examined for content of MPs (Neves et al., 2015a). These were found in 17 species (about $20 \%$ of the total). Of all the fish that ingested MPs, $63.5 \%$ was benthic and $36.5 \%$ pelagic species. Fibers dominated over irregular fragments, with pelagic fish ingesting more particles and benthic fish ingesting more fibers, in relation to the presence of high quantities of fibers in seabed sediments (Woodall et al., 2014). Fish with the highest number of MPs were from the mouth of the Tagus River, in relation to the presence of higher concentrations of bottom marine litter at this location (Neves et al., 2015b), and to riverine inputs from the densely populated metropolitan area of Lisbon. The mackerel Scomber japonicus showed the highest average MP ingestion, suggesting its potential as indicator species to monitor trends of ingested litter in marine regions regulated by the Marine Strategy Framework Directive (EU, 2008).

Beside digestive tracts, the liver was investigated for the occurrence of MPs in commercial zooplanktivorous fish collected in the Mediterranean Sea (Gulf of Lions, France), specifically the European anchovy (Engraulis encrasicolus), the European pilchard (Sardina pil chardus), and the Atlantic herring (Clupea harengus) (Collard et al., 2017). The results revealed that MPs, mainly PE, were translocated into the livers of the three clupeids. In anchovy, $80 \%$ of livers contained relatively large MPs (124 $438 \mu \mathrm{m})$, showing a high level of contamination. Two translocation pathways were proposed: (i) large particles found in the liver resulted from the agglomeration of smaller pieces; (ii) particle translocation through the intestinal barrier (Collard et al., 2017). Abbasi et al. (2018) investigated MP occurrence in gastrointestinal tracts, skin, muscle, gills and liver of commercially relevant demersal and pelagic fish (Cynoglossus abbreviates, Platycephalus indicus, Saurida tumbil, Sillago sihama) in the Musa estuary and at a site in the Persian Gulf. MP occurrence was widespread in all analysed tissues, although larger size particles were found in the gills and gas trointestinal tracts than in other organs. The means of entry of MPs into tissues not involved in digestion was not clarified, but it was suggested to be related to both translocation and adherence. No MPs $(>20 \mu \mathrm{m})$ were detected in the livers or muscles of Asian seabass specimen (La teolabrax maculatus) sampled in coastal and estuary areas of China, while their prevalence in gut and gill were confirmed (Su et al., 2019). By comparing their results with previous investigations (Abbasi et al., 2018; Collard et al., 2017), the Authors postulated that the relatively big size and shape of the fragments limited their translocation from the intestinal tract to the organs through the circulatory system.

Studies on wild fish populations like those described above provided relevant information about routes of exposure, tissue distribution, and residual body burden under natural exposure scenarios; however, confounding factors mostly related to the methodological issues on sample extraction and handling procedures for MP evaluations may occur (Lusher et al., 2017). Laboratory experiments with model fish species and fluorescently labelled MPs allowed the identification of specific routes and factors promoting MP translocation to selected or gans as well as those organs/tissues potentially more impacted by MP accumulation (Fig. 1). For example, tissue distribution of MPs in zebrafish was reported to be size dependent. By monitoring accumulation of PS MPs following a 7 days exposure to $5 \mu \mathrm{m}$ and $20 \mu \mathrm{m}$ size particles, $\mathrm{Lu}$ et al. (2016) found $5 \mu \mathrm{m}$ MPs in fish gills, gut, and liver, while $20 \mu \mathrm{m}$ MPs accumulated only in gills and gut. The Authors suggested the possibility for smaller MPs to be transferred to the liver through the circulatory system. Indeed, Kashiwada (2006) showed that medaka fish (Oryzias latipes) accumulated $39.4 \mathrm{~nm}$ PS NPs (10 mg/L waterborne exposure concentration) mainly in gills and intestine, and they were further detected in the brain, testis, liver, and blood; concentrations in blood reached $16.5 \mathrm{ng} / \mathrm{mg}$ protein. Brain accumulation of NPs was further observed in the crucian carp (Carassius carassius) fed with PS NPs through a food chain composed by an algae (Scenedesmus sp.), a crustacean copepod (D. magna) and the carp fish itself (Mattsson et al., 2017), and in the red tilapia (Oreochromis niloticus) exposed to water borne $0.1 \mu \mathrm{m}$ PS NPs (Ding et al., 2018). In both species, neurotoxicity was shown, and in the crucian carp brain tissue structural damages and behavioral disorders were also observed.

A first evidence on maternal transfer of NPs in fish is provided by a laboratory study with zebrafish (Pitt et al., 2018b). Adult females and males (F0 generation) were subjected to dietary exposure to fluores cently labelled PS NPs $(51 \mathrm{~nm})$ for 7 days and bred to produce the F1 generation (Pitt et al., 2018b). Four F1 groups were generated: control (unexposed females and males), maternal (exposed females), paternal (exposed males), and co parental (exposed males and females). PS NPs were found in the yolk sac, gastrointestinal tract, liver, and pancreas of the maternally and co parentally exposed F1 embryos/larvae. These data suggested that PS NPs are maternally transferred to the offspring via accumulation in the eggs of exposed females, probably due to NP interaction with plasma proteins in oocytes. It was also noted that survival and incidence of deformities were not significantly different across groups, although the maternally and co parentally exposed larvae exhibited bradycardia, in agreement with a previous waterborne exposure study (Pitt et al., 2018a).

Larval stages of small fish such as medaka and zebrafish have at tracted much interest as models for studies on tissue distribution of fluorescently labelled NPs because they have transparent bodies, rapid embryo development and organogenesis. Kashiwada (2006) showed that PS particles ( $39.4 \mathrm{~nm}$ to $42 \mu \mathrm{m}$ size) were adsorbed to the chorion in eggs of medaka fish (Oryzias latipes), with $474 \mathrm{~nm}$ particles showing the highest bioavailability to eggs. Particles of the size of $39.4 \mathrm{~nm}$ moved into the yolk and gallbladder during embryonic development. 
Veneman et al. (2017) showed limited PS MP spreading within the zebrafish embryo after injection at the blastula stage, while MP injection in the yolk of 2 day old embryos resulted in redistribution of particles throughout the bloodstream, and accumulation in the heart. van Pomeren et al. (2017) investigated how different uptake routes (chorion and dermal exposure, dermal exposure only, oral and dermal exposure) affected biodistribution of PS NPs and MPs (25, 50, 250 and $700 \mathrm{~nm}$ ) in zebrafish embryos. Particle uptake within the body was observed only following oral exposure, whereas the dermal route resulted in adsorption to the epidermis and gills only. Following ingestion, the particles spread through the body and eventually accumulated in specific organs and tissues, such as the eyes. Particles larger than $50 \mathrm{~nm}$ were predominantly adsorbed onto the intestinal tract and outer epidermis. Embryos exposed to particles via both epidermis and intestine showed highest uptake and MP accumulation in the eye, whereas marginal uptake via the chorion and epidermis was observed.

\section{Physiological impacts of microplastic in aquatic organisms}

There is relatively little consensus regarding the biological impacts of MP pollution. Indeed, while it is clear that large plastic particles (i.e., meso and macroplastics) can cause readily visible effects at the or ganism level, such as suffocation, entangling, or intestinal blockage (Gregory, 2009), the direct and indirect physiological effects of small size particles (micro and nano plastic) on aquatic animals remain elusive. Fig. 2 reports a conceptual scheme resuming known effects of MPs in aquatic species. By following this scheme, we will revise the current literature reporting molecular, cellular effects of MP ingestion that may aid in explaining outcomes observed at the systemic level and up to apical biological endpoints.

\subsection{Molecular and cellular effects}

Biomarker and transcriptional approaches, both "omic" techniques or quantitative real time PCR targeted analyses, are setting the stage of investigations on cellular and molecular mechanisms and sub lethal effects of MPs/NPs on aquatic organisms, revealing main pathways of interaction on immune related responses, stress responses (including antioxidants), cell signaling, and cell energy homeostasis (Fig. 2).

The study from Sussarellu et al. (2016) is amongst the first to infer whole transcriptomic effects of MP exposure in an aquatic organism. Pacific oysters (Crassostrea gigas) were exposed to virgin PS MPs (2 and 6 $\mu \mathrm{m} ; 0.023 \mathrm{mg} / \mathrm{L})$ for 2 months during a reproductive cycle. Transcriptomic profiling suggested a significant shift of energy allocation toward organism maintenance and structural growth at the expense of reproduction. Indeed, when allowed to spawn, MP exposed oysters had significant decreases in oocyte number and diameter, and sperm velocity. The yield of D larvae development of offspring derived from MP exposed parents decreased by $41 \%$ and $18 \%$, respectively, compared with control offspring. Imbalance of energy reserves was also reported by Bour et al. (2018b). A 4 week MP exposure experiment (PE MPs, three size classes: 4 6, 2025 , and $125500 \mu \mathrm{m}$, three concentrations: 1 , 10 , and $25 \mathrm{mg} / \mathrm{kg}$ of sediment) with the sediment dwelling marine clam Ennucula tenuis showed concentration dependent decreases in lipid content and imbalance of total energy reserves.

Using the scleractinian coral Pocillopora damicornis as a model, Tang et al. (2018) reported significant activation of antioxidant enzymes, decreased activity of the detoxifying enzyme glutathione $S$ transferase and the immune enzyme alkaline phosphatase upon coral exposure to 1 $\mu \mathrm{m}$ PS MPs ( $50 \mathrm{mg} / \mathrm{L}, 6 \mathrm{~h}$ to $24 \mathrm{~h}$ exposure). Supporting these find ings, RNA sequencing revealed up regulation of coral transcripts mostly related to stress response and JNK signaling pathway, while down regulated transcripts were involved in sterol transport and EGF ERK1/2 signal pathway. These results suggest that acute MP exposure can activate coral stress response while repressing detoxification and immune system likely through the JNK and ERK signaling pathways. Activation of antioxidant responses mediated by the MAPK/JNK pathway was also observed in the monogonont rotifer Brachionus koreanus and in the marine copepod Paracyclopina nana exposed to 0.05 , 0.5 or $6 \mu \mathrm{m}$ size PS MPs (Jeong et al., 2017, 2016). Freshwater zebra mussels Dreissena polymorpha exposed to PS MPs ( 1 and $10 \mu \mathrm{m}, 6$ day exposure) showed significant modulation of catalase and glutathione peroxidase activities along with increased concentrations of the neurotransmitter dopamine in circulating fluids (Magni et al., 2018). The Authors postulated an implication of dopamine in mediating the elimination processes of ac cumulated MPs by increasing cilia movement in the gut epithelium and in gills, in a manner similar to elimination of pseudo feces, thus MPs being recognized as non food material. Induction of immune related gene products was observed in embryos of zebrafish injected with 700 $\mathrm{nm}$ PS MPs ( $5 \mathrm{mg} / \mathrm{mL}$ ) (Veneman et al., 2017). Notably, RNA sequencing showed enrichment of the complement system, as indicated by up regulation of transcripts in the alternative complement pathway, which is activated by animal interacting with pathogens not bearing antibodies. Interestingly, up regulation of immune related transcripts was observed in early embryo stages of marine mussels ( $M$. gallopro vincialis) exposed to $3 \mu \mathrm{m}$ PS MPs (Capolupo et al., 2018). The uptake activity displayed by embryos towards MPs may have stimulated the immune apparatus, whose function in bivalve early life stages is intrinsically interconnected with the digestive function. Combined analysis of cellular and molecular biomarkers demonstrated that up regulation of lysosome and immune related effectors are primary responses to either virgin or contaminated PS MPs in adults of $M$. gal loprovincialis (Avio et al., 2015a; Gaspar et al., 2018; Paul Pont et al., 2016; Von Moos et al., 2012). Von Moos et al. (2012) showed sig nificant reduction in lysosomal membrane stability paralleled by in creased granulocytoma formation in digestive glands of mussels
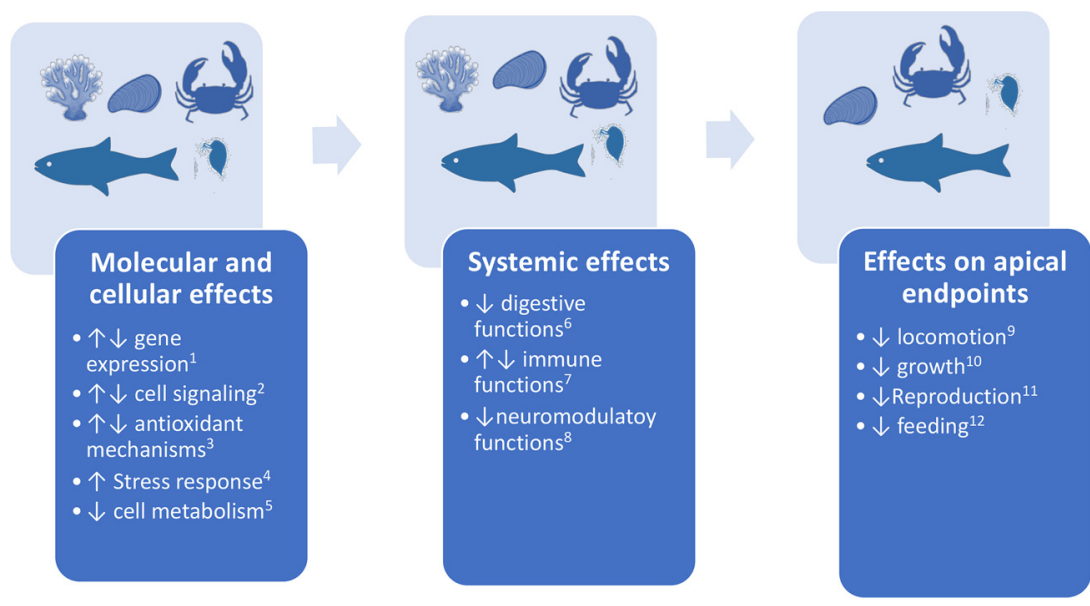

Fig. 2. Resume of the effects at the molecular, cellular, and system levels as well as effects on apical endpoints observed in aquatic organisms interacting with microplastics. ${ }^{1}$ LeMoine et al. (2018); Tang et al. (2018); Jeong et al. (2017). ${ }^{2}$ Tang et al. (2018); Jeong et al. (2017), 2016. ${ }^{3}$ Magni et al. (2018); Tang et al. (2018); Espinosa et al. (2018). ${ }^{4}$ Jeong et al. (2017); Tang et al. (2018). ${ }^{5}$ Bour et al. (2018b); Sussarellu et al. (2016). ${ }^{6}$ Capolupo et al. (2018), (Wen et al. (2018b). ${ }^{7}$ Avio et al. (2015a), (Paul-Pont et al., 2016), Veneman et al. (2017). ${ }^{8}$ LeMoine et al. (2018); Magni et al. (2018). ${ }^{9}$ Chae et al. (2018); Mattsson et al. (2017). ${ }^{10}$ Critchell and Hoogenboom (2018), Foley et al. (2018); RedondoHasselerharm et al. (2018); Watts et al. (2015). ${ }^{11}$ Cole et al. (2015); Foley et al. (2018); Sussarellu et al. (2016); Ziajahromi et al. (2017). ${ }^{12}$ Foley et al. (2018); Lizárraga et al. (2017); Murphy and Quinn (2018). 
exposed in vivo to high density polyethylene (HDPE) MPs (up to $80 \mu \mathrm{m}$ size). The results suggest a clear sequence of responses: particle ingestion (within $3 \mathrm{~h}$ of exposure) is followed by granulocytoma formation (after $6 \mathrm{~h}$ ) at the tissue level, and finally by lysosomal destabilization at the cellular and subcellular level. Nevertheless, Gaspar et al. (2018) found no significant alterations of lysosomal membrane stability in digestive cells of the Eastern oyster (Crassostrea virginica) after both a $4 \mathrm{~h}$ in vitro and a $48 \mathrm{~h}$ in vivo exposure to $50 \mathrm{~nm}$ and $3 \mu \mathrm{m}$ PS particles. RNA sequencing showed the enrichment of the NOD like receptor signaling pathway in mussels exposed to MPs (Avio et al., 2015a). NOD like receptors act as intracellular sensors to recognize both pathogenic patterns entering the cell via phagocytosis, and damage related mole cules produced during cellular stress. They operate by activating the non infectious inflammatory response (Avio et al., 2015a). Further more, virgin PS MPs up regulated various components of the innate immune system, such as putative peptidoglycan recognition proteins. Molecular analyses supported cellular biomarkers also regarding the MP induced modulation of antioxidant defenses, detoxification en zymes, and responses to genotoxic effects (Avio et al., 2015a). The re sults from Paul Pont et al. (2016) and Brandts et al. (2018a) corrobo rated the hypothesis of MPs affecting immune parameters in marine mussels (Mytilus spp.), and further related these effects to increased digestive activities, as some induced immune related proteins play a dual role in bivalve immunity and digestion of microbial food particles.

LeMoine et al. (2018) investigated the molecular underpinnings of the response to MPs in embryos and larvae of the zebrafish exposed to PE particles (10 $45 \mu \mathrm{m} ; 5$ and $20 \mathrm{mg} / \mathrm{L}$ ) for up to 14 days. The most noticeable changes are related to down regulation of transcripts in volved in neuronal functioning, neuron differentiation, and axonogenesis, as well as vision related molecules, such as opsin 6 and rhodopsin. Hints towards neurotoxic effects are reported in juveniles of European seabass (Dicentrarchus labrax) (Barboza et al., 2018). MPs caused acetylcholinesterase (AChE) inhibition, increased lipid oxidation (LPO) in brain and muscle, while changing the activities of the energy related enzymes lactate dehydrogenase (LDH) and isocitrate dehydrogenase (IDH). Although the mechanisms allowing MPs to affect the neurophysiology of fish are not elucidated, it is worth noting that the reported effects do support previous evidences of MP neurotoxicity in different species (Chen et al., 2017; Oliveira et al., 2013). Furthermore, several metabolic transcripts were consistently down regulated in MP treatments, in particular those of the glycolytic pathway and of purine metabolism, suggesting profound changes in cellular metabolic path ways (LeMoine et al., 2018). Differential expression of transcripts related to lipid metabolism in the response to MPs/NPs was further corroborated by (Brandts et al., 2018b) in juveniles of sea bass (D. labrax) after a $96 \mathrm{~h}$ exposure to $\sim 45 \mathrm{~nm}$ polymethylmethacrylate (PMMA) NPs. Interestingly, biochemical endpoints also revealed decreased esterase activity levels in plasma and lower levels of alkaline phosphatase in the skin mucus, suggesting that the immune system of fish might be compromised by exposure to NPs.

\subsection{Systemic effects}

A recent study summarized the results form a total of 130 studies reporting ecotoxicological effects of MPs on aquatic organisms (de Sá et al., 2018). Crustaceans were the most commonly studied group (45\%), followed by fish (21\%), mollusks (18\%), annelid worms (7\%), echinoderms $(7 \%)$ and rotifers $(2 \%)$. These groups occupy different positions in aquatic food webs, with fish generally representing intermediate/top predators that may ingest MPs either directly or feeding on preys containing MPs.

The susceptibility of marine invertebrates towards the physical impacts of MP uptake was first reviewed by Wright et al. (2013), to aid in guiding future research on marine litter and management strategies. The review addressed the factors contributing to the bioavailability of MPs (including size and density), the influence of different feeding strategies, the factors mostly affecting accumulation and translocation, and their trophic transfer through food webs.

Information on the physical impact of MPs in fish has been recently reviewed (Jovanović, 2017), underlying that ingestion of MPs in the gastrointestinal tract of fish can cause different types of histopathological alterations in the intestines. In marine mussels Mytilus spp., exposure to PS MPs (mix of 2 and $6 \mu \mathrm{m}$; final concentration: $32 \mu \mathrm{g} / \mathrm{L}$ ) caused a number of histopathological alterations (Paul Pont et al., 2016). In both fish and mussels, histopathological changes were associated with infiltration of immune cells, suggesting inflammatory processes.

In the last few years, the effects of MPs on feeding, growth, reproduction, and survival of freshwater and marine invertebrates have been increasingly investigated: some representative examples are reported.

In the freshwater cnidarian Hydra attenuata, ingestion of MPs in the form of PE flakes extracted from facewash showed significant impacts on feeding (Murphy and Quinn, 2018). The acute and chronic effects of PS fibers and PE beads were investigated in the crustacean Ceriodaphnia dubia (Ziajahromi et al., 2017). PE fibers posed a greater risk than beads in this species, with reduced reproductive output at concentrations within an order of magnitude of reported environmental levels. Environmental concentrations of PE MPs induced harmful effects on development and emergence of the freshwater sediment dwelling diptera Chironomus tepperi (Ziajahromi et al., 2018). These effects were greatly dependent on particle size, with particles in the size range of $1027 \mu \mathrm{m}$ inducing more pronounced responses (Ziajahromi et al., 2018). Chronic exposure of the amphipod Gammarus pulex exposed to PET fragments (10 $150 \mu \mathrm{m}$ size range) did not affect survival, development (molting), metabolism (glycogen, lipid storage) and feeding activity, despite consistent body accumulation at $24 \mathrm{~h}$ exposure, which largely depended on dose and life stage (i.e. juveniles ingested more MPs than adults) (Weber et al., 2018).

A number of studies have demonstrated the effects of MPs on zooplankton. Attention was initially focused on marine copepods, a globally abundant class that forms a key trophic link between primary producers and higher trophic levels. For example, long term exposure to $20 \mu \mathrm{m}$ PS MPs alter the feeding capacity and decreased reproductive output of the pelagic copepod Calanus helgolandics, with no significant effects on respiration and survival (Cole et al., 2015). In agreement, prolonged exposure to PET MPs (5 $10 \mu \mathrm{m}$ size; 10,000 80,000 particle/ $\mathrm{mL}$ ) had negative effects on the reproductive output of the calanoid copepod Parvocalanus crassirostris, which led to decline of the experimental populations (Heindler et al., 2017). In both studies, the reproductive effectswere attributed to decreased egg size and hatching success related to decreased energy intake by impeded feeding due to MP ingestion. In the freshwater crustacean D. magna ingestion of PET textile fibers resulted in increased mortality regardless of the feeding regime (Jemec et al., 2016). On the other hand, a recent screening study on uptake and effects of four types of environmentally relevant MPs in $D$. magna and Artemia franciscana concluded that zooplankton crustaceans can ingest various MPs but none of the exposure regimens were highly acutely hazardous to the test species (Kokalj et al., 2018). Other contrasting evidence is provided in macroinvertebrates. Watts et al. (2015) investigated the fate of PP rope microfibers ingested by the crab Carcinus maenas and the consequences for the crab energy budget. In chronic feeding studies, crabs that ingested food containing microfibers ( $0.3-1.0 \%$ plastic by weight) showed reduced food consumption; a significant reduction in energy available for growth was observed in crabs fed with $1 \%$ plastic. Interestingly, PP microfibers were physically altered by their passage through the foregut and were excreted with a smaller overall size and amalgamated into distinctive balls. In the mud snail (Potamopyrgus antipodarum) exposure to a large range of environmentally relevant polymers did not affect adult morphological and life-history parameters or juvenile development (Imhof and Laforsch, 2016). 
Due to the ubiquitous presence of MPs in all aquatic environments, risk assessment for biota has become an urgent research priority that needs standardization. In this light, a recent study evaluated the effect thresholds for a battery of six freshwater benthic macroinvertebrates with different species traits, using a wide range of MP concentrations. Standardized 28 days single species bioassays were performed under environmentally relevant exposure conditions using PS MPs (20 - 500 $\mu \mathrm{m}$ ) mixed with sediments (0 $40 \%$ sediment dry weight)(Redondo Hasselerharm et al., 2018). MPs did not affect the survival of Gammarus pulex, Hyalella azteca, Asellus aquaticus, Sphaerium corneum, and Tubifex spp. and no effects were found on the reproduction of the worm Lumbriculus variegatus. No effects on growth were found for all species except for G. pulex, that showed a significant reduction in growth. These results indicate that, although the risks of en vironmentally realistic concentrations of MPs may be low, they still may affect the biodiversity and the functioning of aquatic communities which after all also depend on the sensitive species.

Recent studies focused on the impacts of MPs on development of marine invertebrates. The effects of environmental concentrations of PS MPs were investigated in the sea urchin Paracentrotus lividus and the ascidian Ciona robusta (Messinetti et al., 2018). The feeding strategies of both species proved to be extremely efficient in ingesting MPs. In the presence of microbeads, the metamorphosis of ascidian juveniles was slowed down and development of plutei was altered (Messinetti et al., 2018). Another study on larvae from holothuroids, asteroids and echinoids feeding on $6 \mu \mathrm{m}$ beads in combination with larger inedible beads showed alterations of the feeding rate (Lizárraga et al., 2017). Despite a difference in sensitivity among species, the clearance rate was decreased at increasing particle number. This study pointed out that MPs, probably perceived as inedible particles, can interfere with normal larval feeding and potentially reduce juvenile quality and performance in nature (Lizárraga et al., 2017). In the marineemussel M. galloprovincialis exposure to $3 \mu \mathrm{m}$ PS MPs showed sub lethal impacts on embryolarval development. However, despite the ingestion and retention of MPs in digestive tract over $192 \mathrm{~h}$, MPs did not impair clearance rate and edible food intake (Capolupo et al., 2018).

Overall, available data in both freshwater and marine invertebrates indicate that differences in uptake and effects of MPs may result not only from variations in the exposure regimes (e.g., duration, particle concentrations), plastic characteristics (e.g., type, size, shape, additives), but also from the species specific morphological, physiological and behavioral traits, as well as on the life stage investigated. In this light, the environmental physiology of different species should be considered to identify those traits related to enhanced vulnerability towards MP effects.

A meta analysis of published literature addressed the overall impacts of MPs on consumption (and feeding), growth, reproduction, and survival of fish and aquatic invertebrates (Foley et al., 2018). Although negative effects were observed for all four categories of responses within different groups, many were neutral, indicating a high varia bility of responses across taxa. The most consistent effect was a re duction in consumption of natural prey. In particular, this study un derlined how those organisms serving as prey to larger predators may be particularly susceptible to the negative impacts of MP exposure, with potential for bottom up effects through the food web. In this light, it has been hypothesized that MPs may pose a higher risk to larval fish than other aquatic organisms.

A study carried out on larvae from the European sea bass (Dicentrarchus labrax) fed with different concentrations of fluorescent PE MPs of different sizes demonstrated that, although MPs were de tected in the gastrointestinal tract of all fish, an efficient elimination from the gut was observed after $48 \mathrm{~h}$ depuration (Mazurais et al., 2015). Under these conditions, larval growth and inflammatory responses were not affected, indicating a limited impact on sea bass larvae possibly due to their high potential of egestion. Similarly, no relevant effects of MP ingestion were observed on food consumption and growth of larvae of the fathead minnow (Pimephales promelas) (Malinich et al., 2018). The Authors underlined that fish responses to MPs were highly variable; therefore, care should be taken when interpreting findings of such in dividual studies.

Finally, recent data indicate that ingestion of MPs can induce be havioral changes in fish. In the jacopever fish (Sebastes schlegelii), 14 days exposure to $15 \mu \mathrm{m}$ PS MPs decreased foraging time, and gather exposed fish together (Yin et al., 2018). Similar results were obtained for the Amazonian freshwater cichlid Symphysodon aequifasciatus, in which a 30 days exposure to PE MPs $(7088 \mu \mathrm{m})$ decreased post exposure predatory performance (Wen et al., 2018a). Several hypotheses have been proposed to explain this behavioral impairment. MPs can disturb the digestion process, cause respiratory stress, or disrupt normal functioning of the nervous system, thus indirectly affect fish general behavior. The effects observed at molecular level on transcription of genes related to neuronal function quoted above underline molecular effects on fish neurophysiology.

These observations draw the attention on further implications of MP ingestion that could deplete the fitness of fish populations in natural environments.

\section{The emerging threats of plastic leachates}

Following the evidence on the enormous distribution of plastics in the environment, a great body of studies focused on the ingestion, trophic transfer and toxicity of MPs as small physical entities (Wright et al., 2013). Furthermore, attention is addressed to the possible action of plastic particles as vectors for waterborne contaminant dispersion through the environment and their bioavailability to aquatic organisms (Carbery et al., 2018). Indeed, MPs sorb PBT (persistent, bioaccumulative, and toxic substances), such as PAHs, PCBs, DDT, etc., and these compounds can desorb when MPs are ingested by aquatic species (Engler, 2012). Plastic pellets also pick up metals from the water, that can be transported and ingested (Maršić Lučić et al., 2018). However, some studies pointed out that field investigations provide little evidence that marine MPs affect the global transport of persistent pollutants, and that the ingestion of MPs does not affect bioaccumulation of contaminants in the real environment, despite the evidence from in vitro experiments (Lohmann, 2017). Ingestion of MPs is not likely to increase the risks from exposure to hydrophobic organic chemicals in the aquatic fauna (Koelmans et al., 2016). It is clear that further studies are needed to understand the release processes of MP sorbed contaminants, their trophic transfer and potential adverse effects. This complex issue has very recently been reviewed (Carbery et al., 2018; Wang et al., 2018; Ziccardi et al., 2016).

In this review, we want to shed the light on the another emerging threat that is posed by exposure to compounds deliberately added to help the manufacturing process and give the final product properties to be more usable in specific situations or commercially desirable (Hermabessiere et al., 2017). Since these additives are released from plastics in water or may be leached after animal ingestion, they will be henceforth addressed to as plastic leachates.

\subsection{Plastic additives and leaching propensity}

Plastic products are made from the essential polymer mixed with a complex blend of materials including residual monomers, oligomers, low molecular weight fragments, catalyst remnants, polymerization solvents, and a wide range of further additives (Hermabessiere et al., 2017). With a few exceptions, additives are not chemically bound to the plastic polymer, resulting in the possibility of migrating within the material and reaching the surface, where they can leach out to the environment (Hermabessiere et al., 2017; OECD, 2009).

About 6000 additives of different chemical classes are used in plastic production. Among them, light stabilisers are added to inhibit the reactions in plastics that would cause chemical degradation after 
exposure to UV light. Pigments create a particular colour that render the material more desirable. Plasticisers (e.g. phthalates, epoxides, etc.) are added to make plastics softer and more flexible. Antioxidants (e.g. phenols, arylamines, etc.) are utilized to minimize the deterioration caused by heat, light or chemicals that would favour oxygen combination with hydrocarbons. Flame retardants (e.g. halogens and bromine compounds) are added to prevent ignition or spread of flame in plastic material used in electrical and transport applications which have to meet fire safety standards (Thompson et al., 2009).

Bisphenol A (BPA) is used in a number of applications, including epoxy resin based paints, medical devices, dental sealants, surface coatings, thermal paper commonly used cash receipts (Kang et al., 2003) to make plastics clear and tough. Several studies demonstrated detectable levels in packaged food or beverages (López Cervantes and Paseiro Losada, 2003; Vandermeersch et al., 2015). A great amount of studies indicates BPA as an endocrine disruptor (Oehlmann et al., 2009; Rochester, 2013); as such, it has recently been banned from polycarbonate plastics used in baby bottle manufacturing (Brede et al., 2003). Although it is still allowed in the European Union for use in food containers, a temporary Tolerable Daily Intake (t TDI) of $4 \mu \mathrm{g} / \mathrm{kg}$ bw for BPA has been recently established (EFSA, 2015).

Phthalic acid esters, or phthalates, are a group of chemicals widely used as additive in industrial applications. High molecular weight phthalates, including di(2 ethylhexyl) phthalate (DEHP) and dibutylphthalate (DBP), are used as plasticizers in the manufacture of flexible vinyl plastics. The detected concentrations of DEHP and DBP in drinking waters and surface waters are generally below 1 and $10 \mu \mathrm{g} / \mathrm{L}$ respectively (Liu et al., 2017). Nevertheless, phthalates show many effects as endocrine disruptors in animals as in humans, at low con centrations and not entirely through estrogen mediated pathways (Golshan et al., 2015; Mu et al., 2018; Oehlmann et al., 2009). For example, DEHP (15 30 days of exposure at $10100 \mu \mathrm{g} / \mathrm{L}$ ) reduced sperm production and motility in the goldfish Carassius auratus (Golshan et al., 2015). In the same study, levels of the StAR mRNA, which encodes a regulator of cholesterol transfer to steroidogenesis, and levels of the luteinizing hormone were decreased in DEHP and $17 \beta$ estradiol $(5 \mu \mathrm{g} / \mathrm{L})$ treated goldfish, indicating interference with fish testis and pituitary hormonal functions. However, DEHP did not alter vitellogenin production and transcription of genes mediating estrogenic effects.

$\mathrm{Mu}$ et al. (2018) reported a variety of effects induced by DEHP and dibutyl phthalate (DBP) in zebrafish embryos, including decreased body length, yolk sac abnormities, alteration of immune response, estrogenic effects, and reduced lipid levels. In particular, transcriptomic, proteomic, and lipidomic approaches indicated that the effective concentration of phthalates required to trigger the immune response, to alter lipid homeostasis and yolk sac development was lower than that required to induce estrogenic effects. This finding points out that other pathways may be more sensitive to phthalates than those estrogen mediated. Indeed, the DBP induced morphological alterations were not abolished by inhibitors of estrogen receptors, suggesting that disruption of lipid levels may be a possible alternative mediating the phthalate induced immune response (Mu et al., 2018).

A variety of products, including textiles, thermoplastics used in electronic devices, and products containing polyurethane foams, are added with flame retardant chemicals to ensure insulation, exclude oxygen, and reduce possible combustion. Flame retardants like polybrominated diphenyl ether (PBDEs) may represent up to $30 \%$ by weight of plastic materials (Hermabessiere et al., 2017). Brominated Flame Retardants (BFRs) have been identified in many environmental compartments and also in animals (Guo et al., 2017; Sutton et al., 2019). Differently from compounds of the same class, tetrabromobisphenol A (TBBPA) is chemically bound to the polymer matrix, so that it has nopotential to leach (Morris et al., 2004). No legislation is applied in the European Union to this compound (Vandermeersch et al., 2015). In stead, members of the brominated diphenyl ethers (BDEs) class (i.e. penta and octa BDEs) were banned by the European Union since 2004 (EU, 2003), while deca BDE was banned from electronic and electrical devices since 2009 (European Council Decision, 2009).

Owing to such a variety of plastic additives and their use in high percentage in plastic production, their occurrence in surface and marine waters is not surprising. Additives are found in water and se diments coming from wastewater treatment plan effluents or atmo spheric deposition, in rivers and in coastal environments, and a large proportion is leached by the plastic debris when released in the en vironment ( $\mathrm{Al}$ Odaini et al., 2015). Mato et al. (2001) reported 8.9 to $16 \mu \mathrm{g} / \mathrm{g}$ nonylphenols in PP pellets collected in the Bay of Tokyo. High concentrations of PBDEs, BPA and nonylphenols were found in PE and PP fragments collected along beaches and in open sea areas worldwide (Hirai et al., 2011). BPA, PBDEs and 4 nonylphenol were detected in plastic samples found in the Atlantic Ocean (Rochman et al., 2014). BFRs different from TPPBA are not chemically bound to the plastic polymer, and do leach into the surrounding matrix (Engler, 2012; Meeker et al., 2009). PVC, that can contain $1060 \%$ phthalates by weight, is reported to release phthalates into the environment during manufacturing, use, and disposal (Erythropel et al., 2014; Net et al., 2015).

\subsection{Biological impacts of plastic leachates}

The exposure to leachates is underestimated in the literature despite the well known harmfulness of phenols, phthalates, brominated compounds, etc., which are reported to have adverse effects on the endocrine system of invertebrates and vertebrates, including humans (Canesi and Fabbri, 2015; Correia et al., 2007; Mariana et al., 2016; Sohoni et al., 2001). Chemicals affecting the endocrine system, addressed to as endocrine disruptors (EDCs), act by interacting with specific molecular targets (e.g. hormone receptors, transport proteins, enzymes, etc.) and may produce effects at very low doses. Moreover, depending on the temporal window of the exposure, they may cause long term adverse effects on individuals and their progeny (Alonso Magdalena et al., 2015). It is also worth noting that EDCs behave differently from most toxicants as they do not always follow the classic pharmacological dose response behaviour, and may provoke higher effects at lower concentrations (Vandenberg et al., 2012). These features make investigations on this concern very difficult to perform, and have delayed the definition of regulatory policies. A further challenge is to distinguish contaminants that are sorbed onto the plastics as additives during the industrial manufacturing from those adsorbed from the surrounding medium upon environmental release of plastic fragments (Hermabessiere et al., 2017; León et al., 2018). Furthermore, for most of plastic products the composition is not fully declared by the manufacturers, so that there is a general absence of knowledge on the potential exposure to additives in the environment or through the diet. On the other hand, additives not only leach from the plastic particles, but they may also be absorbed from the water together with other contaminants and then desorbed (León et al., 2018). Thus, the real biological impact of additives deliberatively included during the plastic production is currently not estimated, although additives constitute a very high percentage of the plastic materials and pose a potentially higher exposure risk (Hermabessiere et al., 2017).

Since MPs are also readily ingested by living organisms and trans ferred along the trophic chain, leachates may represent an internal source of contaminants released upon intake (Tanaka et al., 2015). A great body of evidence show the occurrence of plastic leachates in body fluids from invertebrates to vertebrates (Poma et al., 2014; Wang and Zhang, 2013). Many in vitro and in vivo studies showed harmful effects of the above classes of compounds and their metabolites (Lithner et al., 2012), including the interaction with different physiological/endocrine pathways (Canesi et al., 2005; Canesi and Fabbri, 2015).

Very few studies combined leaching tests from plastics and toxicity assays of leachates. The potential leaching of additives from a plastic 
material is due to many factors, including permeability of the polymer matrix, size of gaps between polymer molecules (with the larger favoring the migration), size, solubility and volatility of the additive, $\mathrm{pH}$, temperature, and the chemical/physical properties of the surrounding medium (Kwan and Takada, 2016). The phenomenon also increases with time, and is related to degradation. Lithner et al. (2012) demonstrated that plastics (different classes of polymers) causing acute toxicity (immobilization) to D. magna do leach additives at $\mathrm{pH} 7$ and within a short term exposure $(2472 \mathrm{~h})$. Leachates were mainly composed by hydrophobic compounds. This work also corroborated previous results from the same group (Lithner et al., 2009) indicating that leachates from PVC were the most toxic. However, no direct analysis of the leachate mixture was carried out, thus no information was given on specific additives; at the same time, only acute effects were investigated Bejgarn et al. (2015) compared the acute toxicity of leachates from 21 commercially distributed plastic items (including DVD cases, phone covers, liquid soap bottles, toothbrush covers, soda bottles) after different periods of simulated weathering (including $0192 \mathrm{~h}$ exposure to artificial sunlight) by assessing their lethal effects on the marine copepod Nitocra spinipes. Changes of $\mathrm{pH}$ and smell of the water indicated that new compounds were present in most of the leachates from irradiated objects. Nevertheless, only eight out of the twenty one objects released leachates with lethal effects on the copepods. The irradiation time seemed an important factor to determine the leachate toxicity. Interestingly, weathering of PVC packaging materials increased the toxicity of leachates, while leachates from PVC cables did not show effects. Although this study applied a wide chemical screening approach, it did not assess single chemical composition of the leachates, so a cause effect between specific additives and the observed acute toxicity could not be established.

Larvae of the barnacle Amphibalanus amphitrite were exposed to leachate from seven categories of recyclable commercial plastics (Li et al., 2016). Leachates significantly increased mortality, and the toxicity varied according to the type of plastic tested. In particular, the degree of hydrophobicity was positively correlated with mortality, and PVC was found to be the most toxic material, in agreement with pre vious reports (Lithner et al., 2012, 2009). All plastic leachates sig nificantly inhibited barnacle settlement independently of concentra tions. Chemical analyses revealed different complex mixtures of chemicals included in the plastic classes analysed. In particular, LC MS analysis under the $\mathrm{ESI}^{+}$procedure resulted in a minimum of 113 up to a maximum out of 165 peaks corresponding to the different classes of compounds. Analysis under the ESI procedure resulted in 5 to 7 peaks. After analysis of the leachates for specific ESI ${ }^{+}$compounds, only N,Ndiethyl meta toluamide (DEET) was returned with a confident spectral match score $(>80 \%)$. The Authors concluded that while the leachates were rich in ESI amenable organic substances, those detected are not amongst the commonly monitored organic chemicals (Li et al., 2016).

Leaching experiments with food matrices (e.g. broth, coffee, etc.) widely consumed in expanded polystyrene (EPS) packaging at high temperatures were performed, and leachates used to run toxicity trials on the freshwater crustacean Ceriodaphnia dubia assessed for mortality and reproduction (Thaysen et al., 2018). Some target compounds were expected to be released by EPS but only ethylbenzene was found above the instrumental limit of detection. Leachates affected both biological endpoints, but toxicity did not correlate with ethylbenzene concentrations, suggesting that other substances were released from EPS products that were not targeted by the chemical analyses. Indeed, chemicals which were at concentrations below the limit of detection could have produced cumulative or synergistic effects. Once more, the toxicity of plastic leachate was due to the whole mixtures, mainly of unknown composition.

The toxicity of leachates towards embryo development of brown mussels (Perna perna) was estimated from PP pellets collected in bea ches and virgin ones available commercially (Gandara e Silva et al.,
2016). Effects of leachates from virgin pellets on embryo development depended on the leaching procedure. The toxicity of leachates from beached pellets completely inhibited embryo development in all samples. The different effects of the leachates from beached and virgin PP pellets was related to the mixture of compounds released: the toxicity of leachate from virgin pellets was likely due to plastic additives only, since the pellets had not been exposed to potential contaminants in situ (Gandara e Silva et al., 2016).

Overall, the above data obtained in invertebrate species, including N. spinipes (Bejgarn et al., 2015), A. amphitrite (Li et al., 2016), D. magna (Lithner et al., 2012, 2009), Lytechinus variegatus (Nobre et al., 2015) and P. perna (Gandara e Silva et al., 2016) indicate that leachates from PVC are the most toxic, while leachates from PE and PP are less toxic or not toxic for certain species. Moreover, leachates from virgin plastics are less toxic than those from plastics collected from the environment.

Since chemical features of the most common additives and their harmfulness are known, a better understanding the extent of their capabilities of leaching and the conditions which favour it is needed. A chemical fingerprint of plastic leachates would also be of interest. However, since the investigations demonstrate that each manufacturer uses different molecules for producing plastic objects, designing a common scheme is almost impossible. Nevertheless, specific studies on the real potential of leachates to impair physiological pathways are strongly advisable. In line with the subtle and specific effects of EDCs, a targeted approach has been carried out by Coffin et al. (2018), who explored the influence of weathering processes due to saltwater, UV radiation, and absorption of hydrophobic organic contaminants from the water on leaching of agonists for estrogen receptors (ER) and arylhydrocarbon receptors (AhR) into the aquatic medium. in vitro ex periments were performed with cell lines (immortalized CYP1A1 bla LS180 and VM7Luc4E2) or larvae of the Japanese medaka (O. latipes) challenged with leachates from virgin and irradiated virgin plastics, and with leachates from plastics recovered from the North Pacific Gyre. Analytical chemistry showed that leachates from the plastic materials were rather different, and contaminant levels in leachates from plastics from the North Pacific Gyre were significantly higher than those from irradiated virgin plastics, suggesting that long term weathering may increase the ability of estrogenic plasticizers or other adsorbed compounds to be released into water. The biological effects were also rather different. in vitro estradiol equivalent values for leachates from virgin plastics, UV irradiated virgin plastics and North Pacific gyre recovered plastics were about 4,8 , and $14 \mathrm{ng} / \mathrm{L}$, respectively. A significant 10 fold vitellogenin induction was observed in medaka larvae exposed to leachates from both North Pacific Gyre recovered and UV irradiated virgin plastics. in vitro AhR activity was the highest in North Pacific Gyre recovered plastic than in virgin plastic and UV irradiated virgin plastics (toxic equivalency equal to about $1,0.4$ and $0.7 \mathrm{ng} / \mathrm{L}$, respectively. Significant CYP1A mRNA up regulation (about 18 fold changes) was observed only in larvae of medaka exposed to leachates from North Pacific gyre recovered plastics. It is worth noting that levels of BPA found in the North Pacific gyre recovered and irradiated virgin plastic leachates $(0.72 .6 \mu \mathrm{g} / \mathrm{L}$ and $0.51 .1 \mu \mathrm{g} / \mathrm{L}$, respectively) are within the range reported to induce significant adverse effects reproductive system of adult fish (Correia et al., 2007; Liu et al., 2017; Sohoni et al., 2001). Across all plastic leachates, the chemically based estrogen equivalent concentrations, referred to BPA, OP, nonylphenol and several phthalates, were under estimated in comparison with the in vitro effects, suggesting the presence of additional compounds which were not targeted or below analytical detection limits. In summary, after 30 days of exposure at UV radiation, leachates from virgin plastic had limited in vitro and in vivo biological activities on ER and AhR. Following irradiation, plastic leachates stimulated AhR activity, which was mostly related to desorbed PCBs. Moreover, in vitro and in vivo estrogenic effects were significantly higher relative to control, and consistent with leaching of BPA and 4 tert octylphenol. The AhR and ER dependent effects of plastic leachates increased significantly with longer exposure 
in the environment as observed incubating North Pacific Gyre re covered plastic. Although Coffin et al. (2018) suggested that data should be interpreted as a worst case scenario, the potential for plastics to leach estrogenic additive and be vector of AhR active pollutants at concentrations causing biological effects clearly emerged.

Overall, most of the different molecules that leach out from plastic materials are often at concentrations lower than analytic detection limits. This reduces the possibility to relate leachate toxicity to a specific chemical fingerprint. The very low concentrations of chemicals do not exclude a cumulative or synergistic toxicity, which in fact was demonstrated by most of toxicity tests on leachates performed so far. It must be stressed that exposure to sub nanomolar concentrations of phenols and phthalates causes significant effects on aquatic fauna (Balbi et al., 2016; Canesi and Fabbri, 2015) as well as on human cells (Ejaredar et al., 2015; Heindel et al., 2015). Thus, the release of ad ditives, although below the detection limits, has to be considered when investigating the potential biological effects of MPs that could be the sum of mechanical and chemical effects. Also, part of the variability encountered when testing plastic toxicity may derive from the unknown amounts of leachates in the different experimental conditions.

Overall, the paucity of data regarding composition of leachates is limiting comprehensive risk assessment of the environmental impacts of plastic debris in the aquatic environment. The toxicity associated with leachates must be addressed to as a mixture effect that would elude conventional single chemical toxicity assessments. Finally, additive leachates should not be disregarded on the basis of their low concentrations, since most of these compounds do act on animal physiology at sub nanomolar doses, producing adverse effects in the long term.

\section{Pathogenic bacteria: hitchhikers of microplastics?}

From the early 2000 's, the attention was already turned to the potential of marine plastic debris, that can travel slowly and passively, to promote survival of the associated biota and to transport organisms towards new environments, favoring the invasion by alien species (Barnes, 2002). Zettler et al. (2013) was the first to call 'Plastisphere' the environment and community associated to floating plastic debris in the sea. In addition to the meiofauna, the heterogeneity and high sur face volume ratio of MPs and filaments offer attractive shelter and create new ecological niches for bacterial communities (De Tender et al., 2015; Keswani et al., 2016).

Bacterial communities associated with plastic debris are mainly composed by keystone species in biofilm formation, other species degrading MPs and some hitchhikers potentially pathogens (De Tender et al., 2015; Debroas et al., 2017). Main bacterial colonies seem to be generally attracted by MPs as a support rather than by the type of polymer component itself (Oberbeckmann et al., 2016). Biofilms are highly heterogeneous environments and offer several ecological ad vantages for multitudes of associated bacteria. Biofilm can accumulate nutrients, offers a protective barrier and associated bacteria can organize the degradation of complex substrates (Kirstein et al., 2016). All these features may promote the establishment and growth of diverse types of bacterial communities, including potential pathogens. Recently, a study on coral reefs in the Asia Pacific region concluded an increased likelihood of disease when corals are in contact with plastic litter (Lamb et al., 2018).

Bacterial communities associated with MPs appear to be different from geographical zones, partially due to abiotic factors (e.g. tem perature or salinity) or because of different bacterial composition of the surrounding water (Debroas et al., 2017; Jiang et al., 2018; Kirstein et al., 2016). Moreover, greater bacterial richness was encountered at lower latitudes (Amaral Zettler et al., 2015). Since the amount of plastic debris may continuously increase, it is expected that the transport and colonization of species towards new environments will increase in the near future.

Due to their long life and low density, MPs can be dispersed by wind and currents from the coast to open ocean over large distances (Cozar et al., 2014). This phenomenon favors the transfer of species from an environment to a new one, allowing the establishment of invasive species. In addition, previous works on microbiome associated to MPs has raised concern about the role of plastic debris as vectors for the dispersal of bacterial pathogens (Keswani et al., 2016; Zettler et al., 2013). In the North Adriatic Sea, the fish pathogenic bacteria Aero monas salmonicida was detected onto MP fragments (Viršek et al., 2017). This pathogen species, native from temperate waters and higher latitudes, is usually not present in the Mediterranean Sea, and its pre sence on MP can represent a new source for contamination to fish. The genus Vibrio, that includes many species that are pathogens for humans and marine organisms, has been encountered in several parts of the World as MP associated communities, with some cases where Vibrio dominated the total abundance of bacteria onto MPs. For example, Kirstein et al. (2016) reported the presence of the human pathogen Vibrio parahaemolyticus on MPs from North and Baltic Seas. Since this strain was also encountered in the surrounding water, the Authors suggested that seawater could serve as a source for MP colonization (Kirstein et al., 2016). Moreover, Vibrio was also present on poly propylene MPs collected in the North Atlantic Ocean and was dom inating the total abundance of bacteria associated with the polymer sample (Zettler et al., 2013). The genus Vibrio was also found in $77 \%$ of the MPs collected in the Bay of Brest (France) (Frère et al., 2018). In optimal conditions, Vibrio has a fast growth that can explain its occa sional dominance on MPs.

MPs can also exert a concentration effect on the distribution of bacteria to living organisms. In most of the cases studied, the bacterial richness was higher on MPs than in the surrounding seawater, demonstrating an attraction effect of bacteria for plastic debris (Bryant et al., 2016; Dussud et al., 2018; Frère et al., 2018). Few pathogens are enough to contaminate the host; hence, if MPs contain pathogenic strains, the number of bacteria entering the organism can be sufficient to cause an infection. Moreover, it is probable that pathogens associated with MPs would be transferred to the food web and persist after passage through the digestive system of the host, where MPs can be enriched in nutrients, this facilitating the growth of other bacterial species. How ever, studies on the marine mussel $M$. edulis and the marine worm Arenicola marina showed no alteration of the microbial composition present on MPs and no enrichment of potential pathogens after the passage through the gut of the animals (Kesy et al., 2017, 2016). Recently, laboratory studies demonstrated that the horizontal gene transfer for antibiotic bacterial resistance was enhanced in MP asso ciated bacteria communities compared to natural aggregates (Arias Andres et al., 2018).

Overall, available data indicate that MPs can also pose future socioeconomic problems related to spreading invasive bacterial species, transporting fish or human pathogens over long distances, concentrating bacterial uptake by marine organisms or increasing the transfer of antibiotic resistance genes. Moreover, this phenomenon could be potentially accentuated as biofilm participate in forming a protective layer against UV radiation, increasing the life time of plastic fragments. However, research in this domain is only at its infancy and further studies on composition of bacterial communities on several polymer substrates and transfer of genetic elements is required.

\section{Conclusions and perspectives}

Microplastics represent a global challenge affecting aquatic ecosystems. Given the recent emergence of research in this field, harmonized approaches for the identification and quantification of plastic particles in water and biota are still lacking.

From a risk assessment perspective, it is necessary to developcomprehensive and agreed methodologies to be included in routine biomonitoring programs, especially for the study of exposure to smaller MPs or to NPs. To this concern, the use of mussels as sentinel species for 
largescale monitoring programs has recently been proposed (Li et al., 2019), and a first attempt to build a Species Sensitivity Distribution (SSD) was proposed as a starting point for possible regulatory guidance (Burns and Boxall, 2018). The SSD was built using ecotoxicity data from marine and freshwater species related to particles of the 10 to $5000 \mathrm{~mm}$ size fraction (most relevant to environmental size distributions). When compared with the measured environmental concentration (MEC), the resulting effective concentrations show that risks are lim ited, although some species and life stages appear particularly sensitive (Burns and Boxall, 2018; Foley et al., 2018). However, ecotoxicity ap proaches do not consider the mechanisms of action and the sublethal effects of MPs that may affect physiology in different model organisms also below SSD derived effective levels. Therefore, knowledge on the effects at the cell/ tissue level is necessary, in particular when con sidering smaller MPs and NPs. Indeed, particles of this size have the potential to pass biological membranes, and consequent implications of adverse effects at the molecular and subcellular levels are of great concern. Moreover, the possible effects of additives have been under estimated so far. Additives occur at high percentage in plastic items, and are reported to leach in the surrounding medium. They are present in leachates at very low concentrations, but those same concentrations are able to affect physiological modulations at the endocrine level (Balbi et al., 2016).

On the whole, this review points out the need for investigations to be performed under a physiological perspective. In this light, evaluating the effects of MPs at the molecular, cellular, tissue/organ and in dividual level and using multi system approaches will allow to identify potential common targets of MPs in different species and at different life stages that can be related to changes in selected physiological functions, including immune and stress related responses, cell sig naling, and energy homeostasis. Integrated and multilevel approaches will help to advance the understanding the biological impacts of MPs in aquatic biota.

\section{Conflicts of interest}

None.

\section{Acknowledgments}

This study was funded by the Joint Program Initiative (JPI) Oceans project PLASTOX (Direct and indirect ecotoxicological impacts of mi croplastics on marine organisms), grant agreement $N^{\circ} 495696324$ (http://www.jpi oceans.eu/plastox).

\section{References}

Abbasi, S., Soltani, N., Keshavarzi, B., Moore, F., Turner, A., Hassanaghaei, M., 2018. Microplastics in different tissues of fish and prawn from the Musa Estuary, Persian Gulf. Chemosphere 205, 80-87. https://doi.org/10.1016/j.chemosphere.2018.04 076 .

Allen, A.S., Seymour, A.C., Rittschof, D., 2017. Chemoreception drives plastic consumption in a hard coral. Mar. Pollut. Bull. 124, 198-205. https://doi.org/10.1016/j. marpolbul.2017.07.030.

Al-Odaini, N.A., Shim, W.J., Han, G.M., Jang, M., Hong, S.H., 2015. Enrichment of hexabromocyclododecanes in coastal sediments near aquaculture areas and a wastewater treatment plant in a semi-enclosed bay in South Korea. Sci. Total Environ. 505, 290-298. https://doi.org/10.1016/j.scitotenv.2014.10.019.

Alonso-Magdalena, P., García-Arévalo, M., Quesada, I., Nadal, Á., 2015. Bisphenol-a treatment during pregnancy in mice: a new window of susceptibility for the development of diabetes in mothers later in life. Endocrinology 156, 1659-1670. https:// doi.org/10.1210/en.2014-1952.

Amaral-Zettler, L.A., Zettler, E.R., Slikas, B., Boyd, G.D., Melvin, D.W., Morrall, C.E. Proskurowski, G., Mincer, T.J., 2015. The biogeography of the Plastisphere: implications for policy. Front. Ecol. Environ. 13, 541-546. https://doi.org/10.1890/ 150017.

Andrady, A.L., 2017. The plastic in microplastics: a review. Mar. Pollut. Bull. 119, 12-22. https://doi.org/10.1016/j.marpolbul.2017.01.082.

Arias-Andres, M., Klümper, U., Rojas-Jimenez, K., Grossart, H.-P., 2018. Microplastic pollution increases gene exchange in aquatic ecosystems. Environ. Pollut. 237, 253-261. https://doi.org/10.1016/j.envpol.2018.02.058.
Au, S.Y., Lee, C.M., Weinstein, J.E., van den Hurk, P., Klaine, S.J., 2017. Trophic transfer of microplastics in aquatic ecosystems: identifying critical research needs. Integr. Environ. Assess. Manag. 13, 505-509. https://doi.org/10.1002/ieam.1907.

Avio, C.G., Gorbi, S., Milan, M., Benedetti, M., Fattorini, D., D’Errico, G., Pauletto, M., Bargelloni, L., Regoli, F., 2015a. Pollutants bioavailability and toxicological risk from microplastics to marine mussels. Environ. Pollut. 198, 211-222. https://doi.org/10. 1016/j.envpol.2014.12.021

Avio, C.G., Gorbi, S., Regoli, F., 2015b. Experimental development of a new protocol for extraction and characterization of microplastics in fish tissues: first observations in commercial species from Adriatic Sea. Mar. Environ. Res. 111, 18-26. https://doi. org/10.1016/j.marenvres.2015.06.014.

Balbi, T., Franzellitti, S., Fabbri, R., Montagna, M., Fabbri, E., Canesi, L., 2016. Impact of bisphenol A (BPA) on early embryo development in the marine mussel Mytilus galloprovincialis: effects on gene transcription. Environ. Pollut. 218, 996-1004. https:// doi.org/10.1016/j.envpol.2016.08.050.

Barboza, L.G.A., Vieira, L.R., Branco, V., Figueiredo, N., Carvalho, F., Carvalho, C., Guilhermino, L., 2018. Microplastics cause neurotoxicity, oxidative damage and energy-related changes and interact with the bioaccumulation of mercury in the European seabass, Dicentrarchus labrax (Linnaeus, 1758). Aquat. Toxicol. 195, 49-57. https://doi.org/10.1016/j.aquatox.2017.12.008.

Barnes, D.K.A., 2002. Invasions by marine life on plastic debris. Nature 416, 808-809. https://doi.org/10.1038/416808a.

Bejgarn, S., MacLeod, M., Bogdal, C., Breitholtz, M., 2015. Toxicity of leachate from weathering plastics: an exploratory screening study with Nitocra spinipes. Chemosphere 132, 114-119. https://doi.org/10.1016/j.chemosphere.2015.03.010. Bour, A., Avio, C.G., Gorbi, S., Regoli, F., Hylland, K., 2018a. Presence of microplastics in benthic and epibenthic organisms: influence of habitat, feeding mode and trophic level. Environ. Pollut. 243, 1217-1225. https://doi.org/10.1016/j.envpol.2018.09. 115

Bour, A., Haarr, A., Keiter, S., Hylland, K., 2018b. Environmentally relevant microplastic exposure affects sediment-dwelling bivalves. Environ. Pollut. 236, 652-660. https:// doi.org/10.1016/j.envpol.2018.02.006.

Brandts, I., Teles, M., Gonçalves, A.P., Barreto, A., Franco-Martinez, L., Tvarijonaviciute, A., Martins, M.A., Soares, A.M.V.M., Tort, L., Oliveira, M., 2018a. Effects of nanoplastics on Mytilus galloprovincialis after individual and combined exposure with carbamazepine. Sci. Total Environ. 643, 775-784. https://doi.org/10.1016/j. scitotenv.2018.06.257.

Brandts, I., Teles, M., Tvarijonaviciute, A., Pereira, M.L., Martins, M.A., Tort, L., Oliveira, M., 2018b. Effects of polymethylmethacrylate nanoplastics on Dicentrarchus labrax. Genomics 110, 435-441. https://doi.org/10.1016/j.ygeno.2018.10.006.

Bråte, I.L.N., Blázquez, M., Brooks, S.J., Thomas, K.V., 2018. Weathering impacts the uptake of polyethylene microparticles from toothpaste in Mediterranean mussels ( $M$. galloprovincialis). Sci. Total Environ. 626, 1310-1318. https://doi.org/10.1016/j. scitotenv.2018.01.141.

Brede, C., Fjeldal, P., Skjevrak, I., Herikstad, H., 2003. Increased migration levels of bisphenol A from polycarbonate baby bottles after dishwashing, boiling and brushing. Food Addit. Contam. 20, 684-689. https://doi.org/10.1080/ 0265203031000119061.

Browne, M.A., Galloway, T., Thompson, R., 2017. Microplastic-an emerging contaminant of potential concern? Integr. Environ. Assess. Manag. 3, 559-561. https://doi.org/10.

1897/1551-3793(2007)3[559:LD]2.0.CO;2.

Browne, M.A., Dissanayake, A., Galloway, T.S., Lowe, D.M., Thompson, R.C., 2008. Ingested microscopic plastic translocates to the circulatory system of the mussel, Mytilus edulis (L.). Environ. Sci. Technol. 42, 5026-5031. https://doi.org/10.1021/ es800249a.

Bryant, J.A., Clemente, T.M., Viviani, D.A., Fong, A.A., Thomas, K.A., Kemp, P., Karl, D.M., White, A.E., DeLong, E.F., 2016. Diversity and activity of communities inhabiting plastic debris in the North Pacific gyre. mSystems 1https://doi.org/10 1128/mSystems.00024-16. e00024-16.

Burns, E.E., Boxall, A.B.A., 2018. Microplastics in the aquatic environment: evidence for or against adverse impacts and major knowledge gaps. Environ. Toxicol. Chem. 37, 2776-2796. https://doi.org/10.1002/etc.4268.

Canesi, L., Corsi, I., 2016. Effects of nanomaterials on marine invertebrates. Sci. Total Environ. 565, 933-940. https://doi.org/10.1016/j.scitotenv.2016.01.085.

Canesi, L., Fabbri, E., 2015. Environmental effects of BPA. Dose-Response 13https://doi. org/10.1177/1559325815598304. 155932581559830.

Canesi, L., Lorusso, L.C., Ciacci, C., Betti, M., Gallo, G., 2005. Effects of the brominated flame retardant tetrabromobisphenol-A (TBBPA) on cell signaling and function of Mytilus hemocytes: involvement of MAP kinases and protein kinase C. Aquat. Toxicol. 75, 277-287. https://doi.org/10.1016/j.aquatox.2005.08.010.

Canesi, L., Ciacci, C., Fabbri, R., Balbi, T., Salis, A., Damonte, G., Cortese, K., Caratto, V., Monopoli, M.P., Dawson, K., Bergami, E., Corsi, I., 2016. Interactions of cationic polystyrene nanoparticles with marine bivalve hemocytes in a physiological environment: role of soluble hemolymph proteins. Environ. Res. 150, 73-81. https:// doi.org/10.1016/j.envres.2016.05.045.

Capolupo, M., Franzellitti, S., Valbonesi, P., Sanz, C., Fabbri, E., 2018. Uptake and transcriptional effects of polystyrene microplastics in larval stages of the Mediterranean mussel Mytilus galloprovincialis. Environ. Pollut. 241, 1038-1047. https://doi.org/10.1016/j.envpol.2018.06.035.

Carbery, M., O'Connor, W., Palanisami, T., 2018. Trophic transfer of microplastics and mixed contaminants in the marine food web and implications for human health Environ. Int. 115, 400-409. https://doi.org/10.1016/j.envint.2018.03.007.

Chae, Y., Kim, D., Kim, S.W., An, Y.J., 2018. Trophic transfer and individual impact of nano-sized polystyrene in a four-species freshwater food chain. Sci. Rep. 8, 1-11. https://doi.org/10.1038/s41598-017-18849-y.

Chen, Q., Gundlach, M., Yang, S., Jiang, J., Velki, M., Yin, D., Hollert, H., 2017. 
Quantitative investigation of the mechanisms of microplastics and nanoplastics toward zebrafish larvae locomotor activity. Sci. Total Environ. 584-585, 1022-1031. https://doi.org/10.1016/j.scitotenv.2017.01.156.

Chubarenko, I., Bagaev, A., Zobkov, M., Esiukova, E., 2016. On some physical and dynamical properties of microplastic particles in marine environment. Mar. Pollut. Bull. https://doi.org/10.1016/j.marpolbul.2016.04.048

Coffin, S., Dudley, S., Taylor, A., Wolf, D., Wang, J., Lee, I., Schlenk, D., 2018. Comparisons of analytical chemistry and biological activities of extracts from North Pacific gyre plastics with UV-treated and untreated plastics using in vitro and in vivo models. Environ. Int. 121, 942-954. https://doi.org/10.1016/j.envint.2018.10.012.

Cole, M., Lindeque, P., Fileman, E., Halsband, C., Goodhead, R., Moger, J., Galloway, T.S., 2013. Microplastic ingestion by zooplankton. Environ. Sci. Technol. 47, 6646-6655. https://doi.org/10.1021/es400663f.

Cole, M., Lindeque, P., Fileman, E., Halsband, C., Galloway, T.S., 2015. The impact of polystyrene microplastics on feeding, function and fecundity in the marine copepod Calanus helgolandicus. Environ. Sci. Technol. 49, 1130-1137. https://doi.org/10. 1021/es504525u.

Collard, F., Gilbert, B., Compère, P., Eppe, G., Das, K., Jauniaux, T., Parmentier, E., 2017. Microplastics in livers of European anchovies (Engraulis encrasicolus, L.). Environ. Pollut. 229, 1000-1005, https://doi.org/10.1016/j.envpol.2017.07.089.

Correia, A.D., Freitas, S., Scholze, M., Goncalves, J.F., Booij, P., Lamoree, M.H., Mañanós, E., Reis-Henriques, M.A., 2007. Mixtures of estrogenic chemicals enhance vitellogenic response in sea bass. Environ. Health Perspect. 115, 115-121. https://doi.org/ 10.1289/ehp.9359.

Cozar, A., Echevarria, F., JI, G.-G., Irigoien, X., Ubeda, B., H.-L, S., Palma, A.T., Navarro,

S., G.-L, J., Ruiz, A., F.-P, M.L., Duarte, C.M., 2014. Plastic debris in the open ocean. Proc. Natl. Acad. Sci. 111, 10239. https://doi.org/10.1073/pnas.1314705111. Critchell, K., Hoogenboom, M.O., 2018. Effects of microplastic exposure on the body condition and behaviour of planktivorous reef fish (Acanthochromis polyacanthus). PLoS One 13https://doi.org/10.1371/journal.pone.0193308. e0193308.

Dacey, J.W.H., Wakeham, S.G., 1986. Oceanic dimethylsulfide: production during zooplankton grazing on phytoplankton. Science (80-.) 233, 1314-1316. https://doi.org/ 10.1126/science.233.4770.1314

Dawson, A., Huston, W., Kawaguchi, S., King, C., Cropp, R., Wild, S., Eisenmann, P., Townsend, K., Bengtson Nash, S.M., 2018. Uptake and depuration kinetics influence microplastic bioaccumulation and toxicity in antarctic krill (Euphausia superba). Environ. Sci. Technol. 52, 3195-3201. https://doi.org/10.1021/acs.est.7b05759.

de Sá, L.C., Oliveira, M., Ribeiro, F., Rocha, T.L., Futter, M.N., 2018. Studies of the effects of microplastics on aquatic organisms: what do we know and where should we focus our efforts in the future? Sci. Total Environ. 645, 1029-1039. https://doi.org/10. 1016/j.scitotenv.2018.07.207.

De Tender, C.A., Devriese, L.I., Haegeman, A., Maes, S., Ruttink, T., Dawyndt, P., 2015. Bacterial community profiling of plastic litter in the Belgian part of the North Sea.

Environ. Sci. Technol. 49, 9629-9638. https://doi.org/10.1021/acs.est.5b01093. DeBose, J.L., Lema, S.C., Nevitt, G.A., 2008. Dimethylsulfoniopropionate as a foraging cue for reef fishes. Science (80-.) 319, 1356. https://doi.org/10.1126/science. 1151109.

Debroas, D., Mone, A., Ter Halle, A., 2017. Plastics in the North Atlantic garbage patch: a boat-microbe for hitchhikers and plastic degraders. Sci. Total Environ. 599-600, 1222-1232. https://doi.org/10.1016/j.scitotenv.2017.05.059.

Ding, J., Zhang, S., Razanajatovo, R.M., Zou, H., Zhu, W., 2018. Accumulation, tissue distribution, and biochemical effects of polystyrene microplastics in the freshwater fish red tilapia (Oreochromis niloticus). Environ. Pollut. 238, 1-9. https://doi.org/10. 1016/j.envpol.2018.03.001.

Dussud, C., Meistertzheim, A.L., Conan, P., Pujo-Pay, M., George, M., Fabre, P., Coudane, J., Higgs, P., Elineau, A., Pedrotti, M.L., Gorsky, G., Ghiglione, J.F., 2018. Evidence of niche partitioning among bacteria living on plastics, organic particles and surrounding seawaters. Environ. Pollut. 236, 807-816. https://doi.org/10.1016/j. envpol.2017.12.027.

EFSA, 2015. Scientific Opinion on the risks to public health related to the presence of bisphenol A (BPA) in foodstuffs: part I - exposure assessment. EFSA J. 13, 1-386. EFSA,

2016. Statement on the presence of microplastics and nanoplastics in food, with particular focus on seafood. EFSA J. 14, 4501-4531.

Ejaredar, M., Nyanza, E.C., Ten Eycke, K., Dewey, D., 2015. Phthalate exposure and childrens neurodevelopment: a systematic review. Environ. Res. 142, 51-60. https:// doi.org/10.1016/j.envres.2015.06.014.

Engler, R.E., 2012. The complex interaction between marine debris and toxic chemicals in the ocean. Environ. Sci. Technol. 46, 12302-12315. https://doi.org/10.1021/ es3027105.

Eriksson, C., Burton, H., 2003. Origins and biological accumulation of small plastic particles in fur seals from Macquarie Island. AMBIO A J. Hum. Environ. 32, 380-384. https://doi.org/10.1639/0044-7447(2003)032[0380:OABAOS]2.0.CO;2.

Erythropel, H.C., Maric, M., Nicell, J.A., Leask, R.L., Yargeau, V., 2014. Leaching of the plasticizer di(2-ethylhexyl)phthalate (DEHP) from plastic containers and the question of human exposure. Appl. Microbiol. Biotechnol. 98, 9967-9981. https://doi.org/10. 1007/s00253-014-6183-8.

Espinosa, C., García Beltrán, J.M., Esteban, M.A., Cuesta, A., 2018. In vitro effects of virgin microplastics on fish head-kidney leucocyte activities. Environ. Pollut. 235, 30-38. https://doi.org/10.1016/j.envpol.2017.12.054.

EU, 2003. Directive 2003/11/EC of the European Parliament and of the Council of 6 February 2003 Amending for the 24th Time Council Directive 76/769/EEC Relating to Restrictions on the Marketing and Use of Certain Dangerous Substances and Preparations. http://eur-lex.europa.eu/LexUriServ/LexUriServ.do? uri $1 / 4 \mathrm{OJ}$ : L:2003:042:0045:0046:EN:PDF \%0D\%0A (Pentabromodip [WWW Document]. URL (Accessed 20 November 2018).

EU, 2008. Directive 2008/56/EC Marine Strategy Framework Directive. [WWW
Document]. Off. J. Eur. Union.

European Council Decision, 2009. Official Journal of the European Union Commission. Decision 2005/717/EC-Exemption of Deca BDE From the Prohibition on Use, C116. May 9, 2008. http://eur-lex.europa.eu/legal- content/EN/TXT/?uri = CELEX \%3A62006CJ0014 [WWW Document]. URL (Accessed 27 November 2018).

Farrell, P., Nelson, K., 2013. Trophic level transfer of microplastic: Mytilus edulis (L.) to Carcinus maenas (L.). Environ. Pollut. 177, 1-3. https://doi.org/10.1016/j.envpol. 2013.01.046.

Foley, C.J., Feiner, Z.S., Malinich, T.D., Höök, T.O., 2018. A meta-analysis of the effects of exposure to microplastics on fish and aquatic invertebrates. Sci. Total Environ. 631-632, 550-559. https://doi.org/10.1016/j.scitotenv.2018.03.046.

Fossi, M.C., Panti, C., Guerranti, C., Coppola, D., Giannetti, M., Marsili, L., Minutoli, R., 2012. Are baleen whales exposed to the threat of microplastics? A case study of the Mediterranean fin whale (Balaenoptera physalus). Mar. Pollut. Bull. 64, 2374-2379. https://doi.org/10.1016/j.marpolbul.2012.08.013.

Fossi, M.C., Baini, M., Panti, C., Galli, M., Jiménez, B., Muñoz-Arnanz, J., Marsili, L., Finoia, M.G., Ramírez-Macías, D., 2017. Are whale sharks exposed to persistent organic pollutants and plastic pollution in the Gulf of California (Mexico)? First ecotoxicological investigation using skin biopsies. Comp. Biochem. Physiol. Part C Toxicol. Pharmacol. 199, 48-58. https://doi.org/10.1016/j.cbpc.2017.03.002.

Frère, L., Maignien, L., Chalopin, M., Huvet, A., Rinnert, E., Morrison, H., Kerninon, S., Cassone, A.-L., Lambert, C., Reveillaud, J., Paul-Pont, I., 2018. Microplastic bacteria communities in the Bay of Brest: influence of polymer type and size. Environ. Pollut. 242, 614-625. https://doi.org/10.1016/j.envpol.2018.07.023.

Galloway, T.S., Lewis, C.N., 2016. Marine microplastics spell big problems for future generations. Proc. Natl. Acad. Sci. U. S. A. 113, 2331-2333. https://doi.org/10.1073/ pnas. 1600715113 .

Galloway, T.S., Cole, M., Lewis, C., 2017. Interactions of microplastic debris throughout the marine ecosystem. Nat. Ecol. Evol. 1, 1-8. https://doi.org/10.1038/ s41559-017-0116.

Gandara e Silva, P.P., Nobre, C.R., Resaffe, P., Pereira, C.D.S., Gusmão, F., 2016. Leachate from microplastics impairs larval development in brown mussels. Water Res. 106,

364-370. https://doi.org/10.1016/j.watres.2016.10.016.

Gaspar, T.R., Chi, R.J., Parrow, M.W., Ringwood, A.H., 2018. Cellular bioreactivity of micro- and nano-plastic particles in oysters. Front. Mar. Sci. 5, 1-8. https://doi.org/ 10.3389/fmars.2018.00345.

Germanov, E.S., Marshall, A.D., Bejder, L., Fossi, M.C., Loneragan, N.R., 2018. Microplastics: No small problem for filter-feeding megafauna. Trends Ecol. Evol. 33, 227-232. https://doi.org/10.1016/j.tree.2018.01.005.

Gigault, J., Halle, Ater, Baudrimont, M., Pascal, P.-Y., Gauffre, F., Phi, T.-L., El Hadri, H., Grassl, B., Reynaud, S., 2018. Current opinion: what is a nanoplastic? Environ. Pollut. 235, 1030-1034. https://doi.org/10.1016/j.envpol.2018.01.024.

Golshan, M., Hatef, A., Socha, M., Milla, S., Butts, I.A.E., Carnevali, O., Rodina, M., Sokołowska-Mikołajczyk, M., Fontaine, P., Linhart, O., Alavi, S.M.H., 2015. Di-(2ethylhexyl)-phthalate disrupts pituitary and testicular hormonal functions to reduce sperm quality in mature goldfish. Aquat. Toxicol. 163, 16-26. https://doi.org/10. 1016/j.aquatox.2015.03.017.

Gregory, M.R., 2009. Environmental implications of plastic debris in marine settingsentanglement, ingestion, smothering, hangers-on, hitch-hiking and alien invasions. Philos. Trans. R. Soc. B Biol. Sci. 364, 2013-2025. https://doi.org/10.1098/rstb. 2008.0265.

Grigorakis, S., Mason, S.A., Drouillard, K.G., 2017. Determination of the gut retention of plastic microbeads and microfibers in goldfish (Carassius auratus). Chemosphere 169, 233-238. https://doi.org/10.1016/j.chemosphere.2016.11.055

Guo, J., Venier, M., Salamova, A., Hites, R.A., 2017. Bioaccumulation of Dechloranes, organophosphate esters, and other flame retardants in Great Lakes fish. Sci. Total Environ. 583, 1-9. https://doi.org/10.1016/j.scitotenv.2016.11.063.

Güven, O., Gökdă̆, K., Jovanović, B., Kıdeys, A.E., 2017. Microplastic litter composition of the Turkish territorial waters of the Mediterranean Sea, and its occurrence in the gastrointestinal tract of fish. Environ. Pollut. 223, 286-294. https://doi.org/10. 1016/j.envpol.2017.01.025.

Heindel, J.J., vom Saal, F.S., Blumberg, B., Bovolin, P., Calamandrei, G., Ceresini, G. Cohn, B.A., Fabbri, E., Gioiosa, L., Kassotis, C., Legler, J., La Merrill, M., Rizzir, L., Machtinger, R., Mantovani, A., Mendez, M.A., Montanini, L., Molteni, L., Nagel, S.C., Parmigiani, S., Panzica, G., Paterlini, S., Pomatto, V., Ruzzin, J., Sartor, G., Schug, T.T., Street, M.E., Suvorov, A., Volpi, R., Zoeller, R.T., Palanza, P., 2015. Parma consensus statement on metabolic disruptors. Environ. Heal. 14, 54. https://doi.org/ 10.1186/s12940-015-0042-7.

Heindler, F.M., Alajmi, F., Huerlimann, R., Zeng, C., Newman, S.J., Vamvounis, G., van Herwerden, L., 2017. Toxic effects of polyethylene terephthalate microparticles and Di(2-ethylhexyl)phthalate on the calanoid copepod, Parvocalanus crassirostris. Ecotoxicol. Environ. Saf. 141, 298-305. https://doi.org/10.1016/j.ecoenv.2017.03. 029 .

Hermabessiere, L., Dehaut, A., Paul-Pont, I., Lacroix, C., Jezequel, R., Soudant, P., Duflos, G., 2017. Occurrence and effects of plastic additives on marine environments and organisms: a review. Chemosphere 182, 781-793. https://doi.org/10.1016/j. chemosphere.2017.05.096.

Hirai, H., Takada, H., Ogata, Y., Yamashita, R., Mizukawa, K., Saha, M., Kwan, C., Moore, C., Gray, H., Laursen, D., Zettler, E.R., Farrington, J.W., Reddy, C.M., Peacock, E.E., Ward, M.W., 2011. Organic micropollutants in marine plastics debris from the open ocean and remote and urban beaches. Mar. Pollut. Bull. 62, 1683-1692. https://doi org/10.1016/j.marpolbul.2011.06.004.

Imhof, H.K., Laforsch, C., 2016. Hazardous or not - are adult and juvenile individuals of Potamopyrgus antipodarum affected by non-buoyant microplastic particles? Environ. Pollut. 218, 383-391. https://doi.org/10.1016/j.envpol.2016.07.017.

Jabeen, K., Su, L., Li, J., Yang, D., Tong, C., Mu, J., Shi, H., 2017. Microplastics and 
mesoplastics in fish from coastal and fresh waters of China. Environ. Pollut. 221, 141-149. https://doi.org/10.1016/j.envpol.2016.11.055.

Jemec, A., Horvat, P., Kunej, U., Bele, M., Kržan, A., 2016. Uptake and effects of microplastic textile fibers on freshwater crustacean Daphnia magna. Environ. Pollut. 219, 201-209. https://doi.org/10.1016/j.envpol.2016.10.037.

Jeong, C.B., Won, E.J., Kang, H.M., Lee, M.C., Hwang, D.S., Hwang, U.K., Zhou, B., Souissi, S., Lee, S.J., Lee, J.S., 2016. Microplastic size-dependent toxicity, oxidative stress induction, and p-JNK and p-p38 activation in the monogonont rotifer (Brachionus koreanus). Environ. Sci. Technol. 50, 8849-8857. https://doi.org/10. 1021/acs.est.6b01441.

Jeong, C.B., Kang, H.M., Lee, M.C., Kim, D.H., Han, J., Hwang, D.S., Souissi, S., Lee, S.J., Shin, K.H., Park, H.G., Lee, J.S., 2017. Adverse effects of microplastics and oxidative stress-induced MAPK/Nrf2 pathway-mediated defense mechanisms in the marine copepod Paracyclopina nana. Sci. Rep. 7, 1-11. https://doi.org/10.1038/srep41323.

Jiang, P., Zhao, S., Zhu, L., Li, D., 2018. Microplastic-associated bacterial assemblages in the intertidal zone of the Yangtze Estuary. Sci. Total Environ. 624, 48-54. https:// doi.org/10.1016/j.scitotenv.2017.12.105.

Jovanović, B., 2017. Ingestion of microplastics by fish and its potential consequences from a physical perspective. Integr. Environ. Assess. Manag. 13, 510-515. https:// doi.org/10.1002/ieam.1913.

Kang, J.-H., Kito, K., Kondo, F., 2003. Factors influencing the migration of bisphenol a 444.

from cans. J. Food Prot. 66, 1444-1447. https://doi.org/10.4315/0362-028X-66.8.

Kashiwada, S., 2006. Distribution of nanoparticles in the see-through medaka (Oryzias latipes). Environ. Health Perspect. 114, 1697-1702. https://doi.org/10.1289/ehp. 9209.

Keswani, A., Oliver, D.M., Gutierrez, T., Quilliam, R.S., 2016. Microbial hitchhikers on marine plastic debris: human exposure risks at bathing waters and beach environments. Mar. Environ. Res. 118, 10-19. https://doi.org/10.1016/j.marenvres.2016. 04.006.

Kesy, K., Oberbeckmann, S., Müller, F., Labrenz, M., 2016. Polystyrene influences bacterial assemblages in Arenicola marina-populated aquatic environments in vitro. Environ. Pollut. 219, 219-227. https://doi.org/10.1016/j.envpol.2016.10.032.

Kesy, K., Hentzsch, A., Klaeger, F., Oberbeckmann, S., Mothes, S., Labrenz, M., 2017. Fate and stability of polyamide-associated bacterial assemblages after their passage through the digestive tract of the blue mussel Mytilus edulis. Mar. Pollut. Bull. 125, 132-138. https://doi.org/10.1016/j.marpolbul.2017.08.016.

Kim, S.W., Chae, Y., Kim, D., An, Y.-J., 2019. Zebrafish can recognize microplastics as inedible materials: quantitative evidence of ingestion behavior. Sci. Total Environ.

649, 156-162. https://doi.org/10.1016/j.scitotenv.2018.08.310.

Kirstein, I.V., Kirmizi, S., Wichels, A., Garin-Fernandez, A., Erler, R., Löder, M., Gerdts, G., 2016. Dangerous hitchhikers? Evidence for potentially pathogenic Vibrio spp. on microplastic particles. Mar. Environ. Res. 120, 1-8. https://doi.org/10.1016/j. marenvres.2016.07.004.

Koelmans, A.A., Bakir, A., Burton, G.A., Janssen, C.R., 2016. Microplastic as a vector for chemicals in the aquatic environment: critical review and model-supported reinterpretation of empirical studies. Environ. Sci. Technol. 50, 3315-3326. https://doi.org/10.1021/acs.est.5b06069.

Kokalj, A.J., Kunej, U., Skalar, T., 2018. Screening study of four environmentally relevant microplastic pollutants: uptake and effects on Daphnia magna and Artemia franciscana. Chemosphere 208, 522-529. https://doi.org/10.1016/j.chemosphere.2018.05.172. Kolandhasamy, P., Su, L., Li, J., Qu, X., Jabeen, K., Shi, H., 2018. Adherence of microplastics to soft tissue of mussels: a novel way to uptake microplastics beyond ingestion. Sci. Total Environ. 610-611, 635-640. https://doi.org/10.1016/j.scitotenv. 2017.08.053.

Kwan, C.S., Takada, H., 2016. Release of additives and monomers from plastic wastes. In: Takada, H., Karapanagioti, H.K. (Eds.), Hazardous Chemicals Associated with Plastics in the Marine Environment. Springer Int. Publishing, pp. pp. 51-70. https://doi.org/ $10.1007 / 6982016122$

Lamb, J., Willis, B., Fiorenza, E., Couch, C., Howard, R., Rader, D., True, J., Kelly, L., Ahmad, A., Jompa, J., Harvell, C., 2018. Plastic waste associated with disease on

coral reefs. Science 359, 26-29. https://doi.org/10.1126/science.aar3320. Lehtiniemi, M., Hartikainen, S., Näkki, P., Engström-Öst, J., Koistinen, A., Setälä, O., 2018. Size matters more than shape: ingestion of primary and secondary microplastics by small predators. Food Webs 17https://doi.org/10.1016/j.fooweb.2018. e00097. e00097.

LeMoine, C.M.R., Kelleher, B.M., Lagarde, R., Northam, C., Elebute, O.O., Cassone, B.J., 2018. Transcriptional effects of polyethylene microplastics ingestion in developing zebrafish (Danio rerio). Environ. Pollut. 243, 591-600. https://doi.org/10.1016/j. envpol.2018.08.084.

León, V.M., García, I., González, E., Samper, R., Fernández-González, V., MuniateguiLorenzo, S., 2018. Potential transfer of organic pollutants from littoral plastics debris to the marine environment. Environ. Pollut. 236, 442-453. https://doi.org/10.1016/ j.envpol.2018.01.114.

Li, H., Getzinger, G.J., Ferguson, P.L., Orihuela, B., Zhu, M., Rittschof, D., 2016. Effects of toxic leachate from commercial plastics on larval survival and settlement of the barnacle Amphibalanus amphitrite. Environ. Sci. Technol. 50, 924-931. https://doi. org/10.1021/acs.est.5b02781.

Li, J., Lusher, A.L., Rotchell, J.M., Deudero, S., Turra, A., Bråte, I.L.N., Sun, C., Shahadat Hossain, M., Li, Q., Kolandhasamy, P., Shi, H., 2019. Using mussel as a global bioindicator of coastal microplastic pollution. Environ. Pollut. 244, 522-533. https:// doi.org/10.1016/j.envpol.2018.10.032

Lithner, D., Damberg, J., Dave, G., Larsson, Å, 2009. Leachates from plastic consumer products - screening for toxicity with Daphnia magna. Chemosphere 74, 1195-1200. https://doi.org/10.1016/j.chemosphere.2008.11.022.

Lithner, D., Nordensvan, I., Dave, G., 2012. Comparative acute toxicity of leachates from plastic products made of polypropylene, polyethylene, PVC, acrylonitrile-butadiene-styrene, and epoxy to Daphnia magna. Environ. Sci. Pollut. Res. 19, 1763-1772. https://doi.org/10.1007/s11356-011-0663-5.

Liu, Z., Yin, H., Dang, Z., 2017. Do estrogenic compounds in drinking water migrating from plastic pipe distribution system pose adverse effects to human? An analysis of scientific literature. Environ. Sci. Pollut. Res. 24, 2126-2134. https://doi.org/10. 1007/s11356-016-8032-z.

Lizárraga, D., Danihel, A., Pernet, B., 2017. Low concentrations of large inedible particles reduce feeding rates of echinoderm larvae. Mar. Biol. 164, 102. https://doi.org/10. 1007/s00227-017-3134-9.

Lohmann, R., 2017. Microplastics are not important for the cycling and bioaccumulation of organic pollutants in the oceans-but should microplastics be considered POPs themselves? Integr. Environ. Assess. Manag. 13, 460-465. https://doi.org/10.1002/ ieam 1914 .

López-Cervantes, J., Paseiro-Losada, P., 2003. Determination of bisphenol A in, and its migration from, PVC stretch film used for food packaging. Food Addit. Contam. 20,

596-606. https://doi.org/10.1080/0265203031000109495.

Lu, Y., Zhang, Y., Deng, Y., Jiang, W., Zhao, Y., Geng, J., Ding, L., Ren, H., 2016. Uptake and accumulation of polystyrene microplastics in zebrafish (Danio rerio) and toxic effects in liver. Environ. Sci. Technol. 50, 4054-4060. https://doi.org/10.1021/acs. est.6b00183.

Lusher, A.L., Welden, N.A., Sobral, P., Cole, M., 2017. Sampling, isolating and identifying microplastics ingested by fish and invertebrates. Anal. Methods 9, 1346-1360. https://doi.org/10.1039/c6ay02415g.

Macali, A., Semenov, A., Venuti, V., Crupi, V., D’Amico, F., Rossi, B., Corsi, I., Bergami, E., 2018. Episodic records of jellyfish ingestion of plastic items reveal a novel pathway for trophic transference of marine litter. Sci. Rep. 8, 1-5. https://doi.org/10.1038/ s41598-018-24427-7.

Magni, S., Gagné, F., André, C., Della Torre, C., Auclair, J., Hanana, H., Parenti, C.C., Bonasoro, F., Binelli, A., 2018. Evaluation of uptake and chronic toxicity of virgin polystyrene microbeads in freshwater zebra mussel Dreissena polymorpha (Mollusca: Bivalvia). Sci. Total Environ. 631-632, 778-788. https://doi.org/10.1016/j scitotenv.2018.03.075.

Malinich, T.D., Chou, N., Sepúlveda, M.S., Höök, T.O., 2018. No evidence of microplastic impacts on consumption or growth of larval Pimephales promelas. Environ. Toxicol. Chem. 37, 2912-2918. https://doi.org/10.1002/etc.4257.

Mariana, M., Feiteiro, J., Verde, I., Cairrao, E., 2016. The effects of phthalates in the cardiovascular and reproductive systems: a review. Environ. Int. 94, 758-776. https://doi.org/10.1016/j.envint.2016.07.004.

Maršić-Lučić, J., Lušić, J., Tutman, P., Bojanić Varezić, D., Šiljić, J., Pribudić, J., 2018. Levels of trace metals on microplastic particles in beach sediments of the island of Vis, Adriatic Sea. Croatia. Mar. Pollut. Bull. 137, 231-236. https://doi.org/10.1016/ j.marpolbul.2018.10.027

Mato, Y., Isobe, T., Takada, H., Kanehiro, H., Ohtake, C., Kaminuma, T., 2001. Plastic resin pellets as a transport medium for toxic chemicals in the marine environment.

Environ. Sci. Technol. 35, 318-324. https://doi.org/10.1021/es0010498. Mattsson, K.,

Johnson, E.V., Malmendal, A., Linse, S., Hansson, L.A., Cedervall, T., 2017.

Brain damage and behavioural disorders in fish induced by plastic nanoparticle delivered through the food chain. Sci. Rep. 7, 1-7. https://doi.org/10.1038/ s41598-017-10813-0.

Mazurais, D., Ernande, B., Quazuguel, P., Severe, A., Huelvan, C., Madec, L., Mouchel, O., Soudant, P., Robbens, J., Huvet, A., Zambonino-Infante, J., 2015. Evaluation of the impact of polyethylene microbeads ingestion in European sea bass (Dicentrarchus labrax) larvae. Mar. Environ. Res. 112, 78-85. https://doi.org/10.1016/j.marenvres. 2015.09.009.

Meeker, J.D., Sathyanarayana, S., Swan, S.H., 2009. Phthalates and other additives in plastics: human exposure and associated health outcomes. Philos. Trans. R. Soc. B

Biol. Sci. 364, 2097-2113. https://doi.org/10.1098/rstb.2008.0268.

Messinetti, S., Mercurio, S., Parolini, M., Sugni, M., Pennati, R., 2018. Effects of polystyrene microplastics on early stages of two marine invertebrates with different feeding strategies. Environ. Pollut. 237, 1080-1087. https://doi.org/10.1016/j. envpol.2017.11.030.

Mizraji, R., Ahrendt, C., Perez-Venegas, D., Vargas, J., Pulgar, J., Aldana, M., Patricio Ojeda, F., Duarte, C., Galbán-Malagón, C., 2017. Is the feeding type related with the content of microplastics in intertidal fish gut? Mar. Pollut. Bull. 116, 498-500. https://doi.org/10.1016/j.marpolbul.2017.01.008.

Mohsen, M., Wang, Q., Zhang, L., Sun, L., 2019. Microplastic ingestion by the farmed sea cucumber Apostichopus japonicus in China. Environ. Pollut. 245, 1071-1078. https://

doi.org/10.1016/j.envpol.2018.11.083.

Moore, C.J., 2008. Synthetic polymers in the marine environment: a rapidly increasing, long-term threat. Environ. Res. 108, 131-139. https://doi.org/10.1016/j.envres. 2008.07.025.

Morabito, R., Marino, A., La Spada, G., 2012. Nematocytes' activation in Pelagia noctiluca (Cnidaria, Scyphozoa) oral arms. J. Comp. Physiol. A 198, 419-426. https://doi.org/ 10.1007/s00359-012-0720-7.

Morris, S., Allchin, C.R., Zegers, B.N., Haftka, J.J.H., Boon, J.P., Belpaire, C., Leonards, P.E.G., van Leeuwen, S.P.J., de Boer, J., 2004. Distribution and fate of HBCD and TBBPA brominated flame retardants in North Sea Estuaries and aquatic food webs. Environ. Sci. Technol. 38, 5497-5504. https://doi.org/10.1021/es049640i.

Mu, X., Huang, Y., Li, J., Yang, K., Yang, W., Shen, G., Li, X., Lei, Y., Pang, S., Wang, C., Li, X., Li, Y., 2018. New insights into the mechanism of phthalate-induced developmental effects. Environ. Pollut. 241, 674-683. https://doi.org/10.1016/j.envpol. 2018.05.095.

Murphy, F., Quinn, B., 2018. The effects of microplastic on freshwater Hydra attenuato feeding, morphology and reproduction. Environ. Pollut. 234, 487-494. https://doi. org /10.1016/j. envpol.2017.11.029. 
Nelms, S.E., Galloway, T.S., Godley, B.J., Jarvis, D.S., Lindeque, P.K., 2018. Investigating microplastic trophic transfer in marine top predators. Environ. Pollut. 238,

999-1007. https://doi.org/10.1016/j.envpol.2018.02.016.

Net, S., Rabodonirina, S., Sghaier, R.Ben, Dumoulin, D., Chbib, C., Tlili, I., Ouddane, B., 2015. Distribution of phthalates, pesticides and drug residues in the dissolved, particulate and sedimentary phases from transboundary rivers (France-Belgium). Sci. Total Environ. 521-522, 152-159. https://doi.org/10.1016/j.scitotenv.2015.03.087.

Neves, D., Sobral, P., Ferreira, J.L., Pereira, T., 2015a. Ingestion of microplastics by commercial fish off the Portuguese coast. Mar. Pollut. Bull. 101, 119-126. https://

doi.org/10.1016/j.marpolbul.2015.11.008.

Neves, D., Sobral, P., Pereira, T., 2015b. Marine litter in bottom trawls off the Portuguese coast. Mar. Pollut. Bull. 99, 301-304. https://doi.org/10.1016/j.marpolbul.2015.07. 044.

Nicolau, L., Marçalo, A., Ferreira, M., Sá, S., Vingada, J., Eira, C., 2016. Ingestion of marine litter by loggerhead sea turtles, Caretta caretta, in Portuguese continental waters. Mar. Pollut. Bull. 103, 179-185. https://doi.org/10.1016/j.marpolbul.2015. 12.021

Nobre, C.R., Santana, M.F.M., Maluf, A., Cortez, F.S., Cesar, A., Pereira, C.D.S., Turra, A., 2015. Assessment of microplastic toxicity to embryonic development of the sea urchin Lytechinus variegatus (Echinodermata: Echinoidea). Mar. Pollut. Bull. 92, 99-104. https://doi.org/10.1016/j.marpolbul.2014.12.050.

Oberbeckmann, S., Osborn, A.M., Duhaime, M.B., 2016. Microbes on a bottle: substrate, season and geography influence community composition of microbes colonizing marine plastic debris. PLoS One 11https://doi.org/10.1371/journal.pone.0159289. e0159289.

OECD, 2009. Emission Scenario Document on Plastics Additives. OECD Environ. Heal. Saf. Publ. Ser. Emiss. Scenar. Doc. No. 3 Emiss. https://doi.org/Env/jm/mono(2004) $8 /$ rev1.

Oehlmann, J., Schulte-Oehlmann, U., Kloas, W., Jagnytsch, O., Lutz, I., Kusk, K.O., Wollenberger, L., Santos, E.M., Paull, G.C., Van Look, K.J.W., Tyler, C.R., 2009. A critical analysis of the biological impacts of plasticizers on wildlife. Philos. Trans. R. Soc. B Biol. Sci. 364, 2047-2062. https://doi.org/10.1098/rstb.2008.0242.

Oliveira, M., Ribeiro, A., Hylland, K., Guilhermino, L., 2013. Single and combined effects of microplastics and pyrene on juveniles $(0+$ group) of the common goby Pomatoschistus microps (Teleostei, Gobiidae). Ecol. Indic. 34, 641-647. https://doi. org/10.1016/j.ecolind.2013.06.019.

Ory, N.C., Gallardo, C., Lenz, M., Thiel, M., 2018. Capture, swallowing, and egestion of microplastics by a planktivorous juvenile fish. Environ. Pollut. 240, 566-573. https://doi.org/10.1016/j.envpol.2018.04.093.

Paig-Tran, E.W.M., Kleinteich, T., Summers, A.P., 2013. The filter pads and filtration mechanisms of the devil rays: variation at macro and microscopic scales. J. Morphol. 274, 1026-1043. https://doi.org/10.1002/jmor.20160.

Patterson, B.W., Abraham, A.O., MacIver, M.A., McLean, D.L., 2013. Visually guided gradation of prey capture movements in larval zebrafish. J. Exp. Biol. 216 3071-3083. https://doi.org/10.1242/jeb.087742.

Paul-Pont, I., Lacroix, C., González Fernández, C., Hégaret, H., Lambert, C., Le Goïc, N., Frère, L., Cassone, A.L., Sussarellu, R., Fabioux, C., Guyomarch, J., Albentosa, M., Huvet, A., Soudant, P., 2016. Exposure of marine mussels Mytilus spp. to polystyrene microplastics: toxicity and influence on fluoranthene bioaccumulation. Environ. Pollut. 216, 724-737. https://doi.org/10.1016/j.envpol.2016.06.039.

Paul-Pont, I., Tallec, K., Gonzalez-Fernandez, C., Lambert, C., Vincent, D., Mazurais, D. Zambonino-Infante, J.-L., Brotons, G., Lagarde, F., Fabioux, C., Soudant, P., Huvet, A., 2018. Constraints and priorities for conducting experimental exposures of marine organisms to microplastics. Front. Mar. Sci. 5, 252. https://doi.org/10.3389/FMARS. 2018.00252.

Pellini, G., Gomiero, A., Fortibuoni, T., Ferrà, C., Grati, F., Tassetti, A.N., Polidori, P., Fabi, G., Scarcella, G., 2018. Characterization of microplastic litter in the gastrointestinal tract of Solea solea from the Adriatic Sea. Environ. Pollut. 234, 943-952. https://doi.org/10.1016/j.envpol.2017.12.038.

Pitt, J.A., Kozal, J.S., Jayasundara, N., Massarsky, A., Trevisan, R., Geitner, N., Wiesner, M., Levin, E.D., Di Giulio, R.T., 2018a. Uptake, tissue distribution, and toxicity of polystyrene nanoparticles in developing zebrafish (Danio rerio). Aquat. Toxicol. 194 185-194. https://doi.org/10.1016/j.aquatox.2017.11.017.

Pitt, J.A., Trevisan, R., Massarsky, A., Kozal, J.S., Levin, E.D., Di Giulio, R.T., 2018b. Maternal transfer of nanoplastics to offspring in zebrafish (Danio rerio): a case study with nanopolystyrene. Sci. Total Environ. 643, 324-334. https://doi.org/10.1016/j. scitotenv.2018.06.186

Plastics Europe, 2018. Plastics - The Facts 2017. An Analysis of European Plastics Production, Demand and Waste Data, Plastics Ebook.

Poma, G., Volta, P., Roscioli, C., Bettinetti, R., Guzzella, L., 2014. Concentrations and trophic interactions of novel brominated flame retardants, HBCD, and PBDEs in zooplankton and fish from Lake Maggiore (Northern Italy). Sci. Total Environ. 481, 401-408. https://doi.org/10.1016/j.scitotenv.2014.02.063.

Redondo-Hasselerharm, P.E., Falahudin, D., Peeters, E.T.H.M., Koelmans, A.A., 2018. Microplastic effect thresholds for freshwater benthic macroinvertebrates. Environ.

Sci. Technol. 52, 2278-2286. https://doi.org/10.1021/acs.est.7b05367.

Reisser, J., Proietti, M., Shaw, J., Pattiaratchi, C., 2014. Ingestion of plastics at sea: does debris size really matter? Front. Mar. Sci. 1. https://doi.org/10.1016/j.envpol.2013. 02.031

Rochester, J.R., 2013. Bisphenol A and human health: a review of the literature. Reprod. Toxicol. 42, 132-155. https://doi.org/10.1016/j.reprotox.2013.08.008. Rochman, C.M., Lewison, R.L., Eriksen, M., Allen, H., Cook, A.-M., Teh, S.J., 2014. Polybrominated diphenyl ethers (PBDEs) in fish tissue may be an indicator of plastic contamination in marine habitats. Sci. Total Environ. 476-477, 622-633. https://doi. org/10.1016/j.scitotenv.2014.01.058.

Santana, M.F.M., Moreira, F.T., Turra, A., 2017. Trophic transference of microplastics under a low exposure scenario: insights on the likelihood of particle cascading along marine food-webs. Mar. Pollut. Bull. 121, 154-159. https://doi.org/10.1016/j. marpolbul.2017.05.061.

Savoca, M.S., Wohlfeil, M.E., Ebeler, S.E., Nevitt, G.A., 2016. Marine plastic debris emits a keystone infochemical for olfactory foraging seabirds. Sci. Adv. 2, 1-9. https://doi. org $/ 10.1126 /$ sciadv. 1600395 .

Savoca, M.S., Tyson, C.W., McGill, M., Slager, C.J., 2017. Odours from marine plastic debris induce food search behaviours in a forage fish. Proc. R. Soc. B Biol. Sci. 284. https://doi.org/10.1098/rspb.2017.1000.

Scherer, C., Brennholt, N., Reifferscheid, G., Wagner, M., 2017. Feeding type and development drive the ingestion of microplastics by freshwater invertebrates. Sci. Rep. 7, 1-9. https://doi.org/10.1038/s41598-017-17191-7.

Schuyler, Q.A., Wilcox, C., Townsend, K., Hardesty, B.D., Marshall, N.J., 2014. Mistaken identity? Visual similarities of marine debris to natural prey items of sea turtles. BMC Ecol. 14, 1-7. https://doi.org/10.1186/1472-6785-14-14.

Setälä, O., Fleming-Lehtinen, V., Lehtiniemi, M., 2014. Ingestion and transfer of microplastics in the planktonic food web. Environ. Pollut. 185, 77-83. https://doi.org/10. 1016/j.envpol.2013.10.013.

Setälä, O., Norkko, J., Lehtiniemi, M., 2016. Feeding type affects microplastic ingestion in a coastal invertebrate community. Mar. Pollut. Bull. 102, 95-101. https://doi.org/10. 1016/j.marpolbul.2015.11.053.

Sohoni, P., Tyler, C.R., Hurd, K., Caunter, J., Hetheridge, M., Williams, T., Woods, C., Evans, M., Toy, R., Gargas, M., Sumpter, J.P., 2001. Reproductive effects of long-term exposure to Bisphenol A in the fathead minnow (Pimephales promelas). Environ. Sci. Technol. 35, 2917-2925. https://doi.org/10.1021/es000198n.

Su, L., Deng, H., Li, B., Chen, Q., Pettigrove, V., Wu, C., Shi, H., 2019. The occurrence of microplastic in specific organs in commercially caught fishes from coast and estuary area of east China. J. Hazard. Mater. 365, 716-724. https://doi.org/10.1016/j. jhazmat.2018.11.024

Sussarellu, R., Suquet, M., Thomas, Y., Lambert, C., Fabioux, C., Pernet, M.E.J., Le Goïc, N., Quillien, V., Mingant, C., Epelboin, Y., Corporeau, C., Guyomarch, J., Robbens, J., Paul-Pont, I., Soudant, P., Huvet, A., 2016. Oyster reproduction is affected by exposure to polystyrene microplastics. Proc. Natl. Acad. Sci. U. S. A. 113, 2430-2435. https://doi.org/10.1073/pnas.1519019113.

Sutton, R., Chen, D., Sun, J., Greig, D.J., Wu, Y., 2019. Characterization of brominated, chlorinated, and phosphate flame retardants in San Francisco Bay, an urban estuary. Sci. Total Environ. 652, 212-223. https://doi.org/10.1016/j.scitotenv.2018.10.096.

Tanaka, K., Takada, H., Yamashita, R., Mizukawa, K., Fukuwaka, M., Watanuki, Y., 2015. Facilitated leaching of additive-derived PBDEs from plastic by seabirds' stomach oil and accumulation in tissues. Environ. Sci. Technol. 49, 11799-11807. https://doi. org/10.1021/acs.est.5b01376.

Tang, J., Ni, X., Zhou, Z., Wang, L., Lin, S., 2018. Acute microplastic exposure raises stress response and suppresses detoxification and immune capacities in the scleractinian coral Pocillopora damicornis. Environ. Pollut. 243, 66-74. https://doi.org/10.1016/j. envpol.2018.08.045.

Thaysen, C., Stevack, K., Ruffolo, R., Poirier, D., De Frond, H., DeVera, J., Sheng, G., Rochman, C.M., 2018. Leachate from expanded polystyrene cups is toxic to aquatic invertebrates (Ceriodaphnia dubia). Front. Mar. Sci. 5. https://doi.org/10.3389/ fmars.2018.00071.

Thompson, R.C., Moore, C.J., vom Saal, F.S., Swan, S.H., 2009. Plastics, the environment and human health: current consensus and future trends. Philos. Trans. R. Soc. B Biol. Sci. 364, 2153-2166. https://doi.org/10.1098/rstb.2009.0053.

UNEP, 2016. MARINE PLASTIC DEBRIS Global Lessons and Research to Inspire Action, United Nations Environment Programme, Nairobi. https://doi.org/10.1017/ CBO9781107415324.004.

van Pomeren, M., Brun, N.R., Peijnenburg, W.J.G.M., Vijver, M.G., 2017. Exploring uptake and biodistribution of polystyrene (nano)particles in zebrafish embryos at different developmental stages. Aquat. Toxicol. 190, 40-45. https://doi.org/10.1016/j aquatox.2017.06.017.

Vandenberg, L.N., Colborn, T., Hayes, T.B., Heindel, J.J., Jacobs, D.R., Lee, D.-H., Shioda, T., Soto, A.M., vom Saal, F.S., Welshons, W.V., Zoeller, R.T., Myers, J.P., 2012. Hormones and endocrine-disrupting chemicals: low-dose effects and nonmonotonic dose responses. Endocr. Rev. 33, 378-455. https://doi.org/10.1210/er.2011-1050.

Vandermeersch, G., Lourenço, H.M., Alvarez-Muñoz, D., Cunha, S., Diogène, J., CanoSancho, G., Sloth, J.J., Kwadijk, C., Barcelo, D., Allegaert, W., Bekaert, K., Fernandes, J.O., Marques, A., Robbens, J., 2015. Environmental contaminants of emerging concern in seafood - European database on contaminant levels. Environ. Res. 143 29-45. https://doi.org/10.1016/j.envres.2015.06.011.

Veneman, W.J., Spaink, H.P., Brun, N.R., Bosker, T., Vijver, M.G., 2017. Pathway analysis of systemic transcriptome responses to injected polystyrene particles in zebrafish larvae. Aquat. Toxicol. 190, 112-120. https://doi.org/10.1016/j.aquatox.2017.06 014.

Viherluoto, M., Viitasalo, M., 2001a. Temporal variability in functional responses and prey selectivity of the pelagic mysid, Mysis mixta, in natural prey assemblages. Mar. Biol. 138, 575-583. https://doi.org/10.1007/s002270000478.

Viherluoto, M., Viitasalo, M., 2001b. Effect of light on the feeding rates ot pelagic and littoral mysid shrimps: a trade-off between feeding success and predation avoidance. J. Exp. Mar. Bio. Ecol. 261, 237-244. https://doi.org/10.1016/S0022-0981(01) 00277-5.

Viršek, M.K., Lovšin, M.N., Koren, Š., Kržan, A., Peterlin, M., 2017. Microplastics as a vector for the transport of the bacterial fish pathogen species Aeromonas salmonicida. Mar. Pollut. Bull. 125, 301-309. https://doi.org/10.1016/j.marpolbul.2017.08.024.

Von Moos, N., Burkhardt-Holm, P., Köhler, A., 2012. Uptake and effects of microplastics on cells and tissue of the blue mussel Mytilus edulis L. after an experimental exposure. Environ. Sci. Technol. 46, 11327-11335. https://doi.org/10.1021/es302332w.

Vroom, R.J.E., Koelmans, A.A., Besseling, E., Halsband, C., 2017. Aging of microplastics 
promotes their ingestion by marine zooplankton. Environ. Pollut. 231, 987-996. https://doi.org/10.1016/j.envpol.2017.08.088.

Wang, F., Wong, C.S., Chen, D., Lu, X., Wang, F., Zeng, E.Y., 2018. Interaction of toxic chemicals with microplastics: a critical review. Water Res. 139, 208-219. https://doi. org /10.1016/j.watres.2018.04.003.

Wang, W.-X., Zhang, Q., 2013. Dioxin and phthalate uptake and assimilation by the green mussel Perna viridis. Environ. Pollut. 178, 455-462. https://doi.org/10.1016/j. envpol.2013.03.062.

Watts, A.J.R., Lewis, C., Goodhead, R., Beckett, S.J., Moger, J., Tyler, C.R., Galloway, T.S., 2014. Uptake and retention of microplastics by the shore crab Carcinus maenas. Environ. Sci. Technol. 48, 8823-8830.

Watts, A.J.R., Urbina, M.A., Corr, S., Lewis, C., Galloway, T.S., 2015. Ingestion of plastic microfibers by the crab Carcinus maenas and Its effect on food consumption and energy balance. Environ. Sci. Technol. 49, 14597-14604. https://doi.org/10.1021/ acs.est.5b04026.

Weber, A., Scherer, C., Brennholt, N., Reifferscheid, G., Wagner, M., 2018. PET microplastics do not negatively affect the survival, development, metabolism and feeding activity of the freshwater invertebrate Gammarus pulex. Environ. Pollut. 234, 181189. https://doi.org/10.1016/j.envpol.2017.11.014.

Welden, N.A., Abylkhani, B., Howarth, L.M., 2018. The effects of trophic transfer and environmental factors on microplastic uptake by plaice, Pleuronectes plastessa, and spider crab, Maja squinado. Environ. Pollut. 239, 351-358. https://doi.org/10.1016/ j.envpol.2018.03.110.

Wen, B., Jin, S.R., Chen, Z.Z., Gao, J.Z., Liu, Y.N., Liu, J.H., Feng, X.S., 2018a. Single and combined effects of microplastics and cadmium on the cadmium accumulation, an tioxidant defence and innate immunity of the discus fish (Symphysodon aequifasciatus). Environ. Pollut. 243, 462-471. https://doi.org/10.1016/j.envpol.2018.09. 029.

Wen, B., Zhang, N., Jin, S.-R., Chen, Z.-Z., Gao, J.-Z., Liu, Y., Liu, H.-P., Xu, Z., 2018b. Microplastics have a more profound impact than elevated temperatures on the predatory performance, digestion and energy metabolism of an Amazonian cichlid.
Aquat. Toxicol. 195, 67-76. https://doi.org/10.1016/j.aquatox.2017.12.010.

Wieczorek, A.M., Morrison, L., Croot, P.L., Allcock, A.L., MacLoughlin, E., Savard, O., Brownlow, H., Doyle, T.K., 2018. Frequency of microplastics in mesopelagic fishes from the Northwest Atlantic. Front. Mar. Sci. 5, 1-9. https://doi.org/10.3389/fmars 2018.00039.

Woodall, L.C., Sanchez-Vidal, A., Canals, M., Paterson, G.L.J., Coppock, R., Sleight, V Calafat, A., Rogers, A.D., Narayanaswamy, B.E., Thompson, R.C., 2014. The deep sea is a major sink for microplastic debris. R. Soc. Open Sci. 1, 140317. https://doi.org/ 10.1098/rsos.140317.

Wright, S.L., Thompson, R.C., Galloway, T.S., 2013. The physical impacts of microplastics on marine organisms: a review. Environ. Pollut. 178, 483-492. https://doi.org/10. 1016/j.envpol.2013.02.031.

Yin, L., Chen, B., Xia, B., Shi, X., Qu, K., 2018. Polystyrene microplastics alter the behavior, energy reserve and nutritional composition of marine jacopever (Sebastes schlegelii). J. Hazard. Mater. 360, 97-105. https://doi.org/10.1016/j.jhazmat.2018. 07.110.

Zettler, E.R., Mincer, T.J., Amaral-Zettler, L.A., 2013. Life in the "Plastisphere": microbial communities on plastic marine debris. Environ. Sci. Technol. 47, 7137-7146. https:// doi.org/10.1021/es401288x.

Ziajahromi, S., Kumar, A., Neale, P.A., Leusch, F.D.L., 2017. Impact of microplastic beads and fibers on waterflea (Ceriodaphnia dubia) survival, growth, and reproduction: implications of single and mixture exposures. Environ. Sci. Technol. 51, 1339713406. https://doi.org/10.1021/acs.est.7b03574.

Ziajahromi, S., Kumar, A., Neale, P.A., Leusch, F.D.L., 2018. Environmentally relevant concentrations of polyethylene microplastics negatively impact the survival, growth and emergence of sediment-dwelling invertebrates. Environ. Pollut. 236, 425-431. https://doi.org/10.1016/j.envpol.2018.01.094.

Ziccardi, L.M., Edgington, A., Hentz, K., Kulacki, K.J., Kane Driscoll, S., 2016. Microplastics as vectors for bioaccumulation of hydrophobic organic chemicals in the marine environment: a state-of-the-science review. Environ. Toxicol. Chem. 35, 1667-1676. https://doi.org/10.1002/etc.3461. 